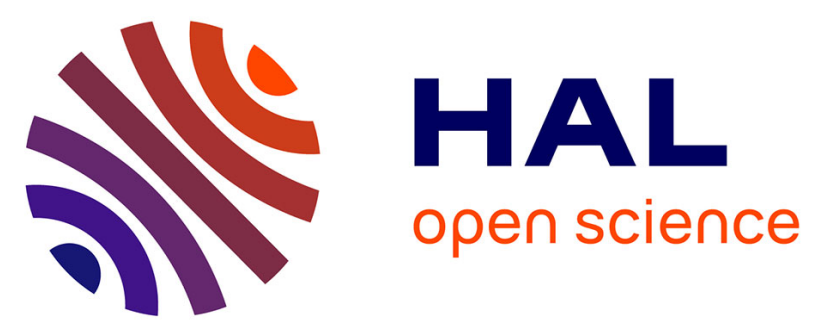

\title{
CXCR4 dimerization and beta-arrestin-mediated signaling account for the enhanced chemotaxis to CXCL12 in WHIM syndrome.
}

\author{
Bernard Lagane, Ken y C Chow, Karl Balabanian, Angelique Levoye, Julie \\ Harriague, Thierry Planchenault, Francoise S Baleux, Nathalie Gunera-Saad, \\ Fernando Arenzana-Seisdedos, Francoise Bachelerie
}

\section{To cite this version:}

Bernard Lagane, Ken y C Chow, Karl Balabanian, Angelique Levoye, Julie Harriague, et al.. CXCR4 dimerization and beta-arrestin-mediated signaling account for the enhanced chemotaxis to CXCL12 in WHIM syndrome.. Blood, 2008, 112 (1), pp.34-44. 10.1182/blood-2007-07-102103 . pasteur00284464

\section{HAL Id: pasteur-00284464}

\section{https://hal-pasteur.archives-ouvertes.fr/pasteur-00284464}

Submitted on 11 Jul 2008

HAL is a multi-disciplinary open access archive for the deposit and dissemination of scientific research documents, whether they are published or not. The documents may come from teaching and research institutions in France or abroad, or from public or private research centers.
L'archive ouverte pluridisciplinaire HAL, est destinée au dépôt et à la diffusion de documents scientifiques de niveau recherche, publiés ou non, émanant des établissements d'enseignement et de recherche français ou étrangers, des laboratoires publics ou privés. 


\title{
CXCR4 dimerization and $\beta$-arrestin-mediated signaling account for the enhanced chemotaxis to CXCL12 in WHIM syndrome
}

\author{
Bernard Lagane ${ }^{1,2,6}$, Ken Y. C. Chow ${ }^{1,2}$, Karl Balabanian ${ }^{1,2,3}$, Angélique Levoye ${ }^{1,2}$, Julie \\ Harriague $^{1,2}$, Thierry Planchenault ${ }^{1,2}$, Françoise Baleux ${ }^{4}$, Nathalie Gunera-saad ${ }^{5}$, Fernando \\ Arenzana-Seisdedos $^{1,2}$, and Françoise Bachelerie ${ }^{1,2}$ \\ ${ }^{(1)}$ Unité de Pathogénie Virale Moléculaire and ${ }^{(4)}$ Unité de Chimie Organique, Institut Pasteur, 75724 Paris, \\ France, ${ }^{(2)}$ INSERM U819, 75724 Paris, France \\ (3) Current address: INSERM U764, Université Paris-Sud 11, Faculté de Médecine Paris Sud, Institut \\ Fédératif de Recherche 13, Clamart, France \\ ${ }^{(5)}$ Universite Lyon1, UFR Lyon-Sud, URCI-LS, CH Lyon-Sud, F-69495 Pierre-Benite \\ (6) Correspondence: Phone: (33) 1456889 45, Fax: (33) 1456889 41, E-mail: lagane@pasteur.fr
}

Running title: $\beta$-arrestin-mediated signaling in WHIM syndrome 


\section{ABSTRACT}

WHIM syndrome is an immune deficiency linked in many cases to heterozygous mutations causing truncations in the cytoplasmic tail of the chemokine receptor CXCR4. Leukocytes expressing truncated CXCR4 display enhanced responses to the receptor ligand CXCL12, including chemotaxis, which likely impair their trafficking and contribute to the immuno-hematological clinical manifestations of the syndrome. CXCR4 desensitization and endocytosis are dependent on $\beta$-arrestin recruitment to the cytoplasmic tail, so that the truncated CXCR4 are refractory to these processes and so have enhanced Gprotein-dependent signaling. Here, we show that the augmented responsiveness of WHIM leukocytes is also accounted for by enhanced $\beta$-arrestin2-dependent signaling downstream of the truncated CXCR4 receptor. Indeed, the WHIM-associated receptor CXCR $4{ }^{1013}$ maintains association with $\beta$-arrestin2 and triggers augmented and prolonged $\beta$-arrestin2-dependent signaling, as revealed by ERK1/2 phosphorylation kinetics. Evidence is also provided that CXCR $4{ }^{1013}$-mediated chemotaxis critically requires $\beta$-arrestin2, and disrupting the SHSK motif in the third intracellular loop of CXCR $4^{1013}$ abrogates $\beta$-arrestin2-mediated signaling, but not coupling to G-proteins, and normalizes chemotaxis. We also demonstrate that CXCR $4{ }^{1013}$ spontaneously forms heterodimers with wild-type CXCR4. Accordingly, we propose a model where enhanced functional interactions between $\beta$-arrestin 2 and receptor dimers account for the altered responsiveness of WHIM leukocytes to CXCL12. 


\section{INTRODUCTION}

The G-protein coupled receptor (GPCR) CXC chemokine receptor 4 (CXCR4) and its ligand, the stromal cell-derived factor-1 (CXCL12/SDF-1), regulate leukocyte hematopoiesis and trafficking. ${ }^{1}$ They initiate

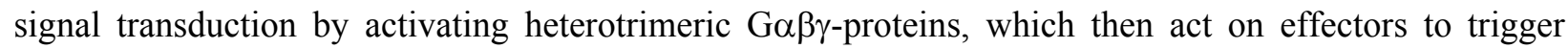
downstream cellular responses. ${ }^{2}$ CXCL12 also elicits processes causing receptor desensitization, which results in the uncoupling from G-proteins and involves phosphorylation of the CXCR4 cytoplasmic tail (C-tail) by protein kinase C and GPCR kinases (GRKs) and interaction of the phosphorylated receptor with $\beta$-arrestins ( $\beta$ arrs).$^{3-5} \beta$ arrs then target desensitized CXCR4 to clathrin-coated pits for endocytosis. Barrs also link GPCRs to the stimulation of additional signaling molecules, including members of the mitogen-activated protein kinase (MAPK) family. ${ }^{6}$ Studies on CXCR4 have demonstrated that $\beta$-arrestin2 ( $\beta$ arr2) strengthens activation of the p38 and extracellular signal-regulated kinase (ERK) MAPKs and CXCL12-induced chemotaxis. ${ }^{5,7,8}$

WHIM syndrome (WS) is a rare immunodeficiency disease linked to CXCR4 dysfunctions and is characterized by warts, recurrent bacterial infections, hypogammaglobulinemia, lymphopenia and myelokathexis, a severe neutropenia with abnormal retention of mature neutrophils in the bone marrow (BM). ${ }^{9,10} \mathrm{WS}$, most often inherited as an autosomal dominant trait, is linked in many cases to heterozygous mutations in CXCR4, so that receptors with truncations of the C-tail are expressed and likely coexist with wild-type receptors $\left(\mathrm{CXCR} 4^{\mathrm{wt}}\right)$ in patients' cells. ${ }^{11-13}$ WHIM leukocytes have enhanced responses to CXCL12, ${ }^{11,12}$ and this might affect their trafficking and so contribute to the clinical manifestations of the WS. For instance, WHIM neutrophils have enhanced chemotactic responsiveness to CXCL12, ${ }^{11,12}$ which may contribute to their abnormal sequestration in the BM. ${ }^{14}$ When expressed in model cells, the WHIM-associated, C-tail truncated receptors $\left(\mathrm{CXCR} 4^{\mathrm{m}}\right)$ are refractory to desensitization and internalization and exhibit enhanced activity, as do receptors in patients' cells, thus suggesting that the abnormal behavior of WHIM leukocytes is due to the mutant receptor dysfunctions. ${ }^{11,12,15}$ Nevertheless, the way in which CXCR $4^{\mathrm{m}}$ function prevails over that of $\mathrm{CXCR} 4^{\mathrm{wt}}$ in WHIM leukocytes is unknown.

The molecular basis of the functional alterations in $\mathrm{CXCR}^{\mathrm{m}}$ also remains incompletely understood. Truncation of the receptor C-tail eliminates phosphorylation sites $^{4}$ and it was therefore 
anticipated that this would diminish $\beta$ arr binding for desensitization and internalization, and hence prolong the activity of receptors and ultimately increase their chemotactic responsiveness to CXCL12. However, this assumption is partly challenged by the fact that CXCR4 requires $\beta$ arr2 for signaling, including chemotaxis. Indeed, lymphocytes from $\beta$ arr2-deficient mice fail to be desensitized in response to CXCL12, but have decreased chemotactic responses. ${ }^{8}$ Here, we show that the inability of CXCR4 to be desensitized and internalized, per se, cannot account for the enhanced chemotaxis in WS. CXCR4 ${ }^{\mathrm{m}}$ preserves functional interactions with $\beta$ arr2, and $\beta$ arr2-mediated signaling contributes to the enhanced CXCL12-mediated migration of WHIM leukocytes. Evidence is also provided that CXCR $4^{\mathrm{m}}$ spontaneously forms heterodimers with $\mathrm{CXCR} 4{ }^{\mathrm{wt}}$. Overall, we propose that enhanced $\beta$ arr2-mediated signaling and heterodimerization between $\mathrm{CXCR} 4^{\mathrm{m}}$ and $\mathrm{CXCR} 4^{\mathrm{wt}}$ are processes whereby responsiveness to CXCL12 is altered in WS. 


\section{MATERIAL AND METHODS}

Cell culture, cDNA constructs and transfections. The HEK 293T (HEK) and A0.01 T cells and the CXCR $4{ }^{1013}$ receptor were described previously. ${ }^{11}$ The $\mathrm{CXCR} 4{ }^{\mathrm{wt} / \Delta \mathrm{i} 3}$ mutant lacking the SHSK motif is from Dr A. Brelot (Institut Cochin, Paris), previously referred to as CXCR4.AICL3-A or $\triangle \mathrm{I} 3-\mathrm{A} .{ }^{16,17}$ The

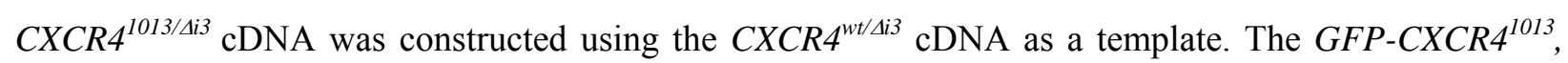

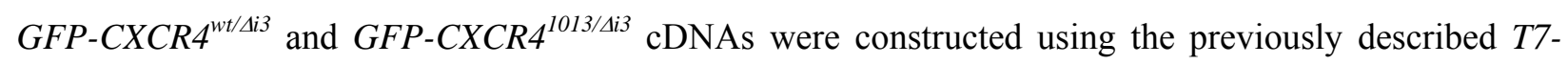
GFP-CXCR ${ }^{w t}{ }^{\mathrm{cDNA}}{ }^{11}$ The CXCR4 cDNAs were cloned into the pTRIP vector and stable expression of receptors was achieved using a lentiviral-based strategy. ${ }^{18}$ The $\mathrm{p} \beta$-arrestin2-eGFP and $\mathrm{pN} 1$-eGFP plasmids previously reported ${ }^{19}$ were from Dr S. Marullo (Institut Cochin, Paris). The CXCR4-Rluc, CXCR4-YFP and CXCR4 ${ }^{1013}$-YFP cDNAs were obtained using the CXCR4 ${ }^{\omega t} \mathrm{cDNA}$ as a template and cloned in frame at the C-tail with the humanized Renilla luciferase (Rluc) or the YFP variant of the GFP into the pCDNA3/CMV-RLuc or the pcDNA3/CMV-GFP Topaze vectors previously described ${ }^{20}$ (from Dr. R. Jockers, Institut Cochin, Paris). The $\mathrm{GABA}_{\mathrm{B} 2}-$ YFP receptor (GBR2-YFP) expression vector is from Dr. M. Bouvier (Université de Montréal, Québec). Transient transfections of plasmids were performed using the calcium phosphate-DNA coprecipitation method, the transfection reagent FuGene 6 (Roche) or the Amaxa Nucleofector technology (Köln, Germany). ßarr2-specific SMARTpoolTM and siCONTROL non-targeting\#1 small interfering RNA (Dharmacon) were transfected in HEK and in A0.01 cells using DharmaFECT 1 (Dharmacon) and the Amaxa Nucleofector technology, respectively. Expression of $\beta$ arr2, $\beta$ arr1 and lactate dehydrogenase (LDH) was assessed by western-blot analysis using a rabbit anti-serum to $\beta$ arr2 (from Dr R.J. Lefkowitz, Durham, USA), a rabbit anti- $\beta$ arr1 mAb (Epitomics) and a sheep anti-human LDH polyclonal Ab (Biodesign).

Patient and sample processing. Pedigree and clinical features of the WHIM patient (P2) were described. ${ }^{11}$ The clinical course of the disease was fatal and the patient died in early 2007. All participating institutions' ethics committee approved this study and patient gave consent for the investigation in accordance to the Declaration of Helsinki. 
Immunoprecipitation assays. In some experiments, cells $\left(10 \times 10^{6}\right)$ were treated with the disuccinimidyl suberate (DSS) cross-linker (Pierce) at a final concentration of $1 \mathrm{mM}$ for $60 \mathrm{~min}$ at RT. The reaction was stopped by addition of $20 \mathrm{mM}$ Tris-HCl, $\mathrm{pH} 7.4$, for $15 \mathrm{~min}$ at $\mathrm{RT}$ and washing once in the same buffer. Cells were then washed in PBS and lysed in $0.2 \mathrm{ml}$ ice-cold lysis buffer (LB, $30 \mathrm{mM}$ HEPES, $100 \mathrm{mM}$ $\mathrm{KCl}, 20 \mathrm{mM} \mathrm{NaCl}, 2 \mathrm{mM} \mathrm{MgCl} 2,5 \%$ glycerol, $2 \%$ Heptanetriol (Fluka), 0.5\% laurylmaltoside, $5 \mu \mathrm{M}$ GDP, $1 \mu \mathrm{M}$ microcystin (Sigma), $1 \mathrm{mM}$ orthovanadate and protease inhibitors (Roche Diagnostics)) for $30 \mathrm{~min}$ at $4^{\circ} \mathrm{C}$. Precleared lysates were incubated overnight at $4^{\circ} \mathrm{C}$ with the anti-CXCR4 mAb $12 \mathrm{G} 5$ precoated on $\gamma$-bind sepharose beads (Amersham). After three washes in LB, immunoprecipitated receptors were eluted in SDS-PAGE sample buffer $(25 \mathrm{mM}$ Tris-HCl, $\mathrm{pH}$ 6.8, 5\% glycerol, 1.5\% SDS, $0.1 \%$ bromophenol blue) for $45 \mathrm{~min}$ at $37^{\circ} \mathrm{C}$, detected by western-blot analysis using the anti-CXCR4 SZ1567 rabbit polyclonal antibody (from Dr M. Thelen, Bellinzona, Switzerland) and quantified using a LAS-1000 CCD camera (Image Gauge 3.4 software).

Functional evaluation of receptors. Receptor cell surface expression was determined by flow cytometry analysis as described, ${ }^{11}$ using the phycoerythrin (PE)-conjugated 12G5 mAb (BD Biosciences). Chemotaxis, receptor down-modulation and $\left[{ }^{35} \mathrm{~S}\right]-\mathrm{GTP} \gamma \mathrm{S}$ binding assays were described. ${ }^{11,21}$ For ERK1/2 phosphorylation, cells were serum-starved for $4 \mathrm{~h}$ and then stimulated by CXCL12 at $37^{\circ} \mathrm{C}$ in RPMI supplemented with $20 \mathrm{mM}$ HEPES $\left(4 \times 10^{6} \mathrm{cells} / \mathrm{ml}\right)$. The reaction was stopped by adding ice-cold RMPI and brief centrifugation at $4^{\circ} \mathrm{C}$, and cells were lysed in ice-cold lysis buffer (20 mM Tris-HCl, $\mathrm{pH} 7.4$, $140 \mathrm{mM} \mathrm{NaCl}, 1 \mathrm{mM}$ EDTA, 1\% NP40, supplemented with phosphatase and protease inhibitors). After centrifugation, ERK2 and phosphorylated ERK1/2 were detected in the supernatants by western-blot analysis using ERK2 (D-2, Santa Cruz) and phospho-p44/42 MAPK (E10, Cell Signaling) mAbs.

Fluorescence imaging. Experiments were performed as described previously. ${ }^{22}$

Microplate BRET assays. HEK cells expressing RLuc- and YFP-tagged receptors were washed once with PBS and $1-2 \times 10^{5}$ cells were distributed into 96-well optiplates (Perkin Elmer). Coelenterazine H substrate (Interchim) was added $(5 \mu \mathrm{M})$ and readings were performed with a microplate reader Mithras 
LB940 (Berthold Technologies), which allows the sequential integration of the signals detected at $480 \pm 20$ $\mathrm{nm}$ and $530 \pm 20 \mathrm{~nm}$ for luciferase and YFP light emissions, respectively. The BRET signal represents the ratio of the light intensity emitted at $530 \mathrm{~nm}$ over the light intensity emitted at $480 \mathrm{~nm}$, and is corrected by subtracting the background signal detected with the RLuc-tagged receptor expressed alone. BRET signals were measured for increasing YFP/RLuc intensity ratios, expressed as percent of the maximal BRET signal (BRETmax), and analyzed with the GraphPad Prism software using nonlinear regression applied to a single binding site model. 


\section{RESULTS}

\section{CXCR4 ${ }^{1013}$ mediates $\beta$ arr2-dependent chemotaxis}

As $\beta$ arr2 is needed for CXCR4-mediated chemotaxis, ${ }^{7,8}$ we hypothesized that $\mathrm{CXCR} 4{ }^{\mathrm{m}}$ preserves functional interactions with $\beta$ arr2. In siblings suffering from WS we identified the CXCR $4^{1013}$ receptor lacking the last fifteen residues of the C-tail as a result of a S338X substitution. ${ }^{11}$ We stably expressed CXCR $4{ }^{1013}$ or $\mathrm{CXCR} 4{ }^{\mathrm{wt}}$ in HEK cells, and association of receptors with $\beta$ arr2 was assessed using coimmunoprecipitation studies following transfection of these cells with a plasmid encoding GFP-tagged Barr2 ( $\beta$ arr2-GFP, Figure 1A). $\beta$ arr2-GFP could be isolated from the CXCR4 ${ }^{1013}$ immunoprecipitates. CXCL12 poorly changed the degree of coimmunoprecipitation, but $\beta$ arr2 recruitment to CXCR4 ${ }^{1013}$ was higher under basal conditions, compared with $\mathrm{CXCR} 4{ }^{\mathrm{wt}}$. Altogether, the data suggest that $\mathrm{CXCR} 4^{1013}$ maintains association with $\beta$ arr2 and preserves $\beta$ arr-mediated signaling.

We thus evaluated the effect of $\beta$ arr2 expression on migration of CXCR $4{ }^{\mathrm{wt}}$ - or CXCR $4^{1013}$ expressing HEK cells toward CXCL12. Cells were transfected with $\beta$ arr2-GFP or the pN1-eGFP vector, and CXCL12-induced migration of cells with green fluorescence was counted (Figure 1B). Following Barr2-GFP expression, the sensitivity of CXCR4 ${ }^{\text {wt }}$-expressing cells to CXCL12 was strongly increased, i.e. the maximal effective concentration of CXCL12 was decreased, as reported. ${ }^{7}$ As we previously described, ${ }^{11}$ CXCR $4^{1013}$-expressing cells demonstrated enhanced chemotaxis. Additionally, CXCR4 ${ }^{1013}$ exhibited higher chemotactic responses with $\beta$ arr2-GFP. Using this approach, we observed that $\beta$ arr2 also regulates CXCL12-induced migration of leukocytes from a healthy individual (CTRL) or a WHIM patient carrying the CXCR $4^{1013}$ receptor (Figure 1C). Notably, WHIM leukocytes displayed stronger chemotactic responses in the presence of $\beta$ arr2-GFP. Overall, this suggests that the CXCR $4{ }^{1013} / \beta$ arr2 interactions contribute to the enhanced chemotaxis mediated by the receptor.

We directly investigated this possibility using siRNA targeting ßarr2, which reduced almost $65 \%$ of endogenous $\beta$ arr2 amounts in $\mathrm{CXCR} 4^{\mathrm{wt}}$ - or CXCR $4^{1013}$-expressing cells (Figure 1D), while expression of $\beta$ arr1 or LDH was not altered. Silencing $\beta$ arr2 expression dramatically reduced the 
chemotaxis of $\mathrm{CXCR} 44^{\mathrm{wt}}$ - or $\mathrm{CXCR} 4{ }^{1013}$-expressing cells (Figure 1E). Of note, the chemotactic responses of CXCR $4^{1013}$ were no longer augmented in $\beta$ arr2-depleted cells, thus indicating that $\beta$ arr2 is critically required for the enhanced chemotactic responsiveness of CXCR $4{ }^{1013}$-expressing cells to CXCL12.

\section{Enhanced CXCR4 ${ }^{1013}$-mediated chemotaxis depends on the SHSK motif in ICL3 of the receptor}

Barr2 was described to interact with the third intracellular loop (ICL3) of CXCR4. ${ }^{5}$ Located in the Nterminal portion of ICL3 is an SHSK motif that is needed for mobilization of intracellular calcium ${ }^{16,17}$ and G-protein-independent stimulation of Jak2/STAT3 in response to CXCL12. ${ }^{16}$ Therefore, we asked whether this motif also plays a role in the enhanced CXCR4 ${ }^{1013}$-mediated chemotaxis (Figure 2). We transduced A0.01 cells, which do not express CXCR4 $4{ }^{23}$ to express similar amounts of CXCR4 ${ }^{\mathrm{wt}}$ or CXCR $4^{1013}$ or their counterparts lacking the SHSK motif, CXCR4 $4^{\mathrm{wt} / \Delta \mathrm{i} 3}$ or $\mathrm{CXCR} 4^{1013 / \Delta \mathrm{i} 3}$ at the cell surface (Figure 2A). Cells were then evaluated for their ability to migrate toward different CXCL12 concentrations (Figure 2B). CXCR $4^{1013}$-expressing cells displayed significantly stronger chemotaxis at the lowest CXCL12 concentrations compared with cells expressing CXCR4 ${ }^{\mathrm{wt}}$ or the SHSK-deleted receptors. The differences in migration were less apparent at higher CXCL12 concentrations, thus indicating that the decrease of the maximal effective chemotactic concentration of CXCL12 is a mechanism whereby CXCR4 $4^{1013}$ enhances responsiveness of cells to the chemokine. Compared with CXCR $4{ }^{\text {wt }}$-expressing cells, cells expressing the CXCR4 $4^{1013 / \Delta i 3}$ receptor lacking both the $\mathrm{C}$-tail and the SHSK motif did not exhibit enhanced CXCL12-induced migration. This indicates that the SHSK motif is needed for the enhanced chemotaxis mediated by CXCR4 ${ }^{1013}$.

\section{Deleting the SHSK motif of CXCR4 ${ }^{1013}$ does not impair G-protein coupling efficiency}

Migration of CXCR4 $4^{\mathrm{wt}}$ - or CXCR $4^{1013}$-expressing cells in response to CXCL12 was fully abrogated in the presence of PTX (Figure 2B), thus indicating that receptor-mediated chemotaxis is dependent upon activation of $\mathrm{G}_{\mathrm{i}}$-proteins. As deletion of the SHSK motif has been reported to prevent CXCR4 from activating $\mathrm{G}_{\mathrm{i}}$-protein dependent signals, ${ }^{16,17}$ we explored whether removing the SHSK motif of CXCR $4{ }^{1013}$ impairs coupling to G-proteins, thereby providing a molecular basis to explaining our data showing that this motif is required for the enhanced chemotactic responses of this receptor. We thus 
measured CXCL12-induced ${ }^{35}$ S-GTP $\gamma \mathrm{S}$ binding to activated $\mathrm{G}_{\alpha}$ subunit-containing membranes from HEK cells expressing similar amounts of $\mathrm{CXCR} 4^{\mathrm{wt}}, \mathrm{CXCR} 4^{1013}, \mathrm{CXCR} 4^{\mathrm{wt} / \Delta \mathrm{i} 3}$ or $\mathrm{CXCR} 4^{1013 / \Delta \mathrm{i} 3}$ (Figure 3A,B). Exposure of membranes from CXCR4 ${ }^{\mathrm{wt}}$-expressing cells to CXCL12 promoted a dose-dependent ${ }^{35} \mathrm{~S}-\mathrm{GTP} \gamma \mathrm{S}$ binding (Figure $3 \mathrm{C}$ ), with a half-maximal effective concentration $\left(\mathrm{EC}_{50}\right)$ in the nanomolar range $\left(\mathrm{EC}_{50}=18 \pm 4 \mathrm{nM}\right)$. Truncation of the C-tail in CXCR4 $4^{1013}$ improved to some extent CXCL12induced coupling efficiency and potency of the receptor $\left(\mathrm{EC}_{50}=12 \pm 2 \mathrm{nM}\right)$, as reported. ${ }^{11}$ By comparison, CXCL12 demonstrated a dramatically reduced efficiency to activate G-proteins from CXCR4 $4^{\mathrm{wt} / \Delta \mathrm{i} 3}$, together with a slightly diminished potency $\left(\mathrm{EC}_{50}=35.6 \pm 2 \mathrm{nM}\right)$, thus indicating a role for the SHSK motif in regulating G-protein coupling. Unexpectedly, deleting the SHSK motif together with the C-tail in CXCR4 (CXCR4 ${ }^{1013 / \Delta i 3}$ ) corrected coupling efficiency to a level equivalent to that observed with $\mathrm{CXCR}^{\mathrm{wt}}$ or $\mathrm{CXCR}^{1013}$, although the $\mathrm{EC}_{50}$ values remained slightly altered $\left(\mathrm{EC}_{50}=36.8 \pm 3 \mathrm{nM}\right)$.

\section{The SHSK motif prevents CXCR4 from constitutive desensitization and down-modulation}

We thus hypothesized that the impaired ability of CXCR4 $4^{\mathrm{wt} / \Delta \mathrm{i} 3}$ to activate G-proteins results from an increased desensitization due to a favored recruitment of $\beta$ arrs to the receptor C-tail. Association of $\beta$ arrs with the CXCR4 C-tail targets the receptor to clathrin-coated pits for endocytosis. ${ }^{4}$ Thus we asked whether the SHSK motif could regulate CXCR4 internalization, with the anticipation that the CXCR $4^{\text {wt } / \Delta \mathrm{i} 3}$ mutant lacking this motif might display an enhanced endocytosis. We quantified the amount of receptors remaining at the surface of HEK cells stably expressing $\mathrm{CXCR} 4^{\mathrm{wt}}, \mathrm{CXCR} 4^{1013}, \mathrm{CXCR} 4^{\mathrm{wt} / \Delta \mathrm{i} 3}$ or CXCR $4^{1013 / \Delta \mathrm{i} 3}$ after exposure to CXCL12 (Figure 3D). The chemokine induced down-modulation of 35$40 \%$ of cell surface $\mathrm{CXCR} 4{ }^{\mathrm{wt}}$, but failed to trigger endocytosis of the C-tail truncated receptors, CXCR $4{ }^{1013}$ or CXCR $4^{1013 / \Delta i 3}$. Surprisingly, CXCR $4^{\mathrm{wt} / \Delta \mathrm{i} 3}$ was also apparently impaired in its ability to be internalized in response to CXCL12.

We next transfected HEK cells expressing the CXCR4 variants with $\beta$ arr2-GFP and then determined cell surface expression of receptors in GFP-positive-gated cells, in the presence or absence of CXCL12 (Figure 4A,B). Barr2-GFP moderately altered basal cell surface expression of CXCR4 ${ }^{\mathrm{wt}}$, and enhanced the receptor down-modulation by CXCL12 by up to $60 \%$. In contrast, $\beta$ arr2-GFP expression 
affected neither basal nor CXCL12-induced down-modulation of CXCR4 ${ }^{1013}$ and CXCR4 $4^{1013 / \Delta i 3}$, thus emphasizing that association with the C-tail is critical for $\beta$ arrs to regulate CXCR4 endocytosis. Finally, Barr2-GFP expression resulted in a remarkable down-modulation of CXCR $4^{\mathrm{wt} / \Delta \mathrm{i} 3}(\approx 55 \%)$ that was poorly increased by CXCL12 (Figure 4B). Receptor cell surface expression as a function of $\beta$ arr2-GFP expression was further studied following transitory co-transfection assays in HEK cells. As depicted in Figure $4 \mathrm{C}$, a proportion of the CXCR $4^{\mathrm{wt}}$-expressing cells with a high $\beta$ arr2-GFP content exhibited downmodulation of receptors. This effect was absent in cells expressing the C-tail truncated receptors CXCR4 $4^{1013}$ and $\mathrm{CXCR} 4^{1013 / \Delta \mathrm{i} 3}$ (Figure 4D,F), but was dramatically magnified in the cells expressing $\mathrm{CXCR} 4^{\mathrm{wt} / \Delta \mathrm{i} 3}$ (Figure 4E). This basal down-modulation of $\mathrm{CXCR} 4^{\mathrm{w} t / \Delta \mathrm{i} 3}$ strongly suggests that $\beta$ arr2 constitutively interacts with the receptor C-tail, i.e. in an agonist independent manner, thus providing an explanation for how CXCR4 $4^{\mathrm{wt} / \Delta \mathrm{i} 3}$ is impaired in its ability to activate G-proteins.

Other GPCRs that undergo constitutive $\beta$ arr-mediated desensitization accumulate intracellularly due to constitutive association with $\beta$ arr $2 .{ }^{24}$ Similarly, using fluorescence microscopy imaging of HEK cells stably expressing GFP-tagged receptors, we demonstrated that CXCR $4{ }^{\mathrm{wt} / \Delta \mathrm{i} 3}$ localized to a higher extent in the cytosol than its wild-type counterpart (Figure 4G). As expected, fluorescence in cells expressing GFP-CXCR $4^{1013}$ or GFP-CXCR $4^{1013 / \Delta \mathrm{i} 3}$ originated mainly from the plasma membrane. Overall, these findings uncover a critical role for the SHSK motif both in preventing CXCR4 from constitutive desensitization and in stabilizing receptor expression at the cell surface.

Our data also indicate that the C-tail truncation of $\mathrm{CXCR} 4^{\mathrm{wt} / \Delta \mathrm{i} 3}$, which results in the CXCR $4^{1013 / \Delta i 3}$ receptor, is sufficient to prevent constitutive desensitization and internalization. However, CXCR $4^{1013 / \Delta i 3}$ does not trigger enhanced CXCL12-induced migration (Figure 2), so that it could be that the refractoriness to desensitization and endocytosis does not account per se for the enhanced chemotaxis mediated by CXCR $4^{1013}$.

\section{CXCR4 $^{1013}$ triggers enhanced and sustained ßarr2-dependent signaling that depends on the SHSK motif}


The archetypal role for $\beta$ arr in signaling is to act as a scaffold for the ERK1/2 MAPK cascade. ${ }^{6}$ As the enhanced chemotaxis of WHIM cells depends on $\beta$ arr2, we hypothesized that increased intensity and/or duration of $\beta$ arr2-dependent signaling occur in WHIM cells. As a first support of this assumption, CXCL12-induced ERK1/2 phosphorylation was dramatically enhanced in leukocytes from a WS patient harboring CXCR $4^{1013}$, compared with a healthy individual (Figure 5A).

Next, we compared the time course of CXCL12-stimulated ERK1/2 activation in A0.01 cells expressing similar amounts of CXCR $4^{\mathrm{wt}}, \mathrm{CXCR} 4^{1013}, \mathrm{CXCR} 4^{\mathrm{wt} / \Delta \mathrm{i} 3}$ or $\mathrm{CXCR} 4^{1013 / \Delta \mathrm{i} 3}$ (Figure 5B,C). In CXCR4 ${ }^{\text {wt }}$-expressing cells, CXCL12-induced ERK1/2 phosphorylation was rapid and transient, reaching a maximum at $2 \mathrm{~min}$ and then declining over time. In CXCR $4{ }^{1013}$-expressing cells, ERK1/2 activation was increased at $2 \mathrm{~min}$ and persisted at longer time points. Interestingly, CXCR4 $4^{1013 / \Delta i 3}$, which similarly to CXCR $4{ }^{1013}$ lacks CXCL12-mediated desensitization and endocytosis, triggered an early peak of ERK1/2 phosphorylation that was also enhanced, but the amount of activated ERK1/2 returned rapidly to levels close to those observed in CXCR $4^{\mathrm{wt}}$-expressing cells. This indicates that refractoriness of receptors to desensitization does not contribute to the overall sustained duration of the ERK1/2 phosphorylation observed in CXCR $4^{1013}$-expressing cells. In contrast, the SHSK motif of CXCR4 $4^{1013}$ is involved in this process. ERK1/2 activation at 2 min was strongly reduced in cells expressing the constitutively desensitized receptor $\mathrm{CXCR} 4{ }^{\mathrm{wt} / \Delta \mathrm{i} 3}$, and remained at a low level over $15 \mathrm{~min}$. This result, together with the fact that $\mathrm{CXCR} 4^{1013}$ and CXCR $4^{1013 / \Delta \mathrm{i} 3}$ elicited an enhanced signal at 2 min, strongly suggests that the early peak of CXCL12-mediated ERK1/2 activation is primarily dependent upon coupling to G-proteins and as such is sensitive to desensitization.

The time course of ERK1/2 activation mediated by CXCR $4{ }^{1013}$ resembles those reported for other GPCRs, ${ }^{25,26}$ which stimulate ERK1/2 by two distinct pathways: one depending on G-protein activation, which is transient and occurs shortly after ligand stimulation, and the other, which is a Gprotein independent, ßarr-mediated pathway, leading to a slower but much more prolonged ERK1/2 activation. Thus, we evaluated whether $\beta$ arr2 could contribute to the sustained duration of the CXCR $4{ }^{1013}$-mediated ERK1/2 activation. Reduction of endogenous $\beta$ arr2 amounts $(\sim 40 \%)$ in CXCR4 $4^{\mathrm{wt}}$ or CXCR $4^{1013}$-expressing A0.01 cells (Figure 6A) effectively diminished the prolonged CXCL12-induced ERK1/2 activation in CXCR $4{ }^{1013}$-expressing cells to levels comparable to those measured in CXCR4 $4^{\mathrm{wt}}$ - 
expressing cells (Figure 6B). This suggests that $\beta$ arr2 contributes to the enhancement of the ERK1/2 phosphorylation observed in $\mathrm{CXCR} 4^{1013}$-expressing cells at the late time points. $\beta$ arr2 depletion also attenuated to some extent $\mathrm{CXCR} 4^{\mathrm{wt}}$-mediated ERK1/2 activation at 15 min of stimulation. Nonetheless, when experiments were repeated at 2 min after CXCL12 stimulation, $\beta$ arr2 depletion did not reduce ERK1/2 activation (Figure 6C), thus indicating that $\beta$ arr2 does not contribute to the early ERK1/2 phosphorylation mediated by $\mathrm{CXCR} 4{ }^{\mathrm{wt}}$ or $\mathrm{CXCR} 4{ }^{1013}$. ERK1/2 activation at 2 min was even higher in ßarr2-silenced cells, thus suggesting that $\beta$ arr2 can exert a dual effect on ERK1/2 activation downstream of these receptors, that is, preventing the early activation of ERK $1 / 2$ and triggering it at later time points.

\section{Spontaneous heterodimerization between CXCR4 ${ }^{1013}$ and CXCR4 ${ }^{\text {wt }}$}

Heterozygous mutations of CXCR4 in WS lead to the expression of CXCR4 $4^{\mathrm{m}}$, which likely coexist with $\mathrm{CXCR}^{\mathrm{wt}}$ in patients' cells. ${ }^{11}$ These cells have enhanced CXCL12-induced chemotaxis and ERK1/2 phosphorylation, as do CXCR $4^{\mathrm{m}}$-expressing cell lines, thus suggesting that $\mathrm{CXCR} 4^{\mathrm{m}}$ alters the $\mathrm{CXCR} 4^{\mathrm{wt}}$ functioning in WHIM cells. In line with this, CXCR4 $4^{1013}$ was found to prevent CXCL12-induced endocytosis of $\mathrm{CXCR} 4^{\mathrm{wt}},{ }^{11}$ thus implying that the receptors heterodimerize when they coexist in the same cell.

To investigate this possibility, we used HEK cells expressing CXCR4 ${ }^{\text {wt }}$ with or without the GFP-CXCR $4^{1013}$ receptor, and association of receptors was assessed using coimmunoprecipitation studies with the DSS cross-linker (Figure 7). In the absence of DSS, immunodetection of precipitated receptors revealed bands with molecular weights close to those expected for monomeric CXCR $4^{\mathrm{wt}}(41 \mathrm{kDa})$ and GFP-CXCR $4^{1013}(\sim 59 \mathrm{kDa})$. Following cross-linking of CXCR $4^{\mathrm{wt}}$ receptors, we detected additional bands of higher molecular masses ( 88 and $123 \mathrm{kDa}$ ) corresponding to CXCR4 ${ }^{\mathrm{wt}}$ dimers and trimers. Similar results were obtained with CXCR4 $4^{1013}$ (data not shown). CXCL12 did not alter the degree of receptor association, thus confirming previous works showing that CXCR4 exists as constitutive oligomers. ${ }^{27,28}$ In the presence of GFP-CXCR $4{ }^{1013}$ we detected a new molecular species at $\sim 100 \mathrm{kDa}$ that was not altered by CXCL12, thus indicating that $\mathrm{CXCR} 4{ }^{\mathrm{wt}}$ and $\mathrm{CXCR} 4{ }^{1013}$ form constitutive heterodimers. The relative abundance of heterodimers was higher than that of CXCR4 ${ }^{\mathrm{wt}}$ or GFP-CXCR $4{ }^{1013}$ homodimers (barely detectable at $\sim 128 \mathrm{kDa}$ ), thus suggesting that heterodimers are preferentially formed. Quantification of 
immunoreactive bands when both receptors are expressed at a $1 / 1$ ratio (right panel) reveals that the extent of heterodimer formation was two-fold higher compared with CXCR $4{ }^{\text {wt }}$ homodimers, which is an expected result if $\mathrm{CXCR} 4{ }^{\mathrm{wt}}$ has the same propensity to self-associate or to interact with $\mathrm{CXCR} 4^{1013}$.

We explored this issue in intact cells using Bioluminescence Resonance Energy Transfer (BRET)-based titration experiments, as described for CXCR $4{ }^{28,29}$ and other receptors. ${ }^{30-32} \mathrm{CXCR} 4{ }^{\mathrm{wt}}$ was fused at the C-tail with Renilla luciferase used as an energy donor (CXCR4 ${ }^{\mathrm{wt}}$-RLuc) and then expressed at a constant amount in HEK cells together with increasing concentrations of C-tail-tagged CXCR $4{ }^{\text {wt }}$ (Figure 7B) or CXCR $4^{1013}$ (Figure 7C) with the BRET acceptor YFP. Then, the extent of energy transfer between RLuc and YFP was plotted as a function of increasing acceptor/donor ratios. As previously reported, ${ }^{28,29}$ $\mathrm{CXCR} 4{ }^{\mathrm{wt}}$ homodimerization is indicated by BRET signals between CXCR $4{ }^{\mathrm{wt}}$-RLuc and CXCR $4{ }^{\mathrm{wt}}-\mathrm{YFP}$ that varied as a hyperbolic function, reaching an asymptote when all CXCR $4^{\mathrm{wt}}$-RLuc molecules are associated with CXCR $4^{\mathrm{wt}}$-YFP. In contrast, coexpressing CXCR $4^{\mathrm{wt}}$-RLuc with YFP alone resulted in nonspecific signals that progressed linearly (Figure 7B). Energy transfer between CXCR ${ }^{\mathrm{wt}}$-RLuc and CXCR $4{ }^{1013}$-YFP also increased hyperbolically with the YFP/RLuc ratios, thus confirming that the receptors spontaneously form heterodimers. The $\mathrm{BRET}_{50}$ values, which correspond to the acceptor/donor ratios resulting in half-maximal saturation of RLuc and represent the propensity of the protomers to interact with one another, ${ }^{33}$ were found to be in the same range for CXCR $4^{\text {wt }}$ homodimer and $\mathrm{CXCR} 4{ }^{\mathrm{wt}} / \mathrm{CXCR} 4{ }^{1013}$ heterodimer formation $\left(\mathrm{BRET}_{50}=21.7 \pm 2.1\right.$ and $9.4 \pm 1.6$, respectively). In contrast, CXCR $4{ }^{\text {wt }}$-RLuc barely associated with the unrelated GPCR, GBR2-YFP, as previously reported, ${ }^{29}$ and as revealed by substantially right-shifted titration curves $\left(\mathrm{BRET}_{50}>100\right.$, Figure $\left.7 \mathrm{C}\right)$. Overall, these results extend to intact cells that $\mathrm{CXCR} 4^{\mathrm{wt}} / \mathrm{CXCR} 4^{1013}$ heterodimers form as efficiently as $\mathrm{CXCR} 4^{\mathrm{wt}}$ homodimers. 


\section{DISCUSSION}

CXCL12/CXCR4 regulate migration, homing and retention of leukocytes within primary lymphoid organs and leukocyte homeostasis in the periphery. ${ }^{1}$ For instance, the BM constitutively expresses CXCL12, and disrupting interaction of the chemokine with CXCR4 cause leukocytosis, with the release of hematopoietic progenitor cells, neutrophils and lymphocytes into the blood. ${ }^{34,35}$ In contrast, increased expression of CXCR4 at the surface of leukocytes augments responsiveness to CXCL12 and improves their accumulation in the BM. ${ }^{14,36,37}$ Individuals with WS suffer from lymphopenia and neutropenia that presumably favor the development of infections and warts. Heterozygous mutations of CXCR4 causing truncations of the receptor $\mathrm{C}$-tail in WS are linked to enhanced responsiveness of leukocytes to CXCL12, ${ }^{11,12}$ thus suggesting that the clinical manifestations may be due to alterations in CXCR4 functioning. In line with this, expression of WHIM-type mutated CXCR4 in healthy human CD34 $4^{+}$stem cells enhances chemotactic responses to CXCL12 and BM engraftment of these cells in a NOD/SCID mouse xenograph model, and myeloid cells with the mutant receptor exhibit reduced release in the blood. ${ }^{14}$ These data support the notion that increased CXCL12-induced chemotaxis, possibly together with greater adherence properties, ${ }^{12}$ contribute to the abnormal sequestration of WHIM neutrophils in the BM. The $\mathrm{CXCR} 4^{\mathrm{m}}$ receptors, including $\mathrm{CXCR} 4^{1013}$, are refractory to desensitization and internalization (this work and ref. ${ }^{11,15}$ ), and it has been anticipated that these results are due to the removal of Ser/Thr residues in the CXCR4 C-tail that are needed for GRK- and Barr-mediated down-modulation of the receptor. ${ }^{4}$ Due to the impaired desensitization, the receptors activate G-proteins more efficiently (Figure 3 and ref. ${ }^{11}$ ) and have improved G-protein-dependent signals in response to CXCL12, such as calcium mobilization $^{13,15}$ or the early ERK1/2 phosphorylation (Figure 5). However, our findings now reveal that physical and functional interactions of $\mathrm{CXCR} 4^{\mathrm{m}}$ receptors with $\beta$ arr2 are actually preserved, and together with heterodimerization with CXCR4 ${ }^{\text {wt }}$, are mechanisms by which CXCR4 activity is altered in WHIM cells and the chemotactic responsiveness to CXCL12 is enhanced. 
We found that the enhanced CXCR $4^{1013}$-mediated chemotaxis is not exclusively related to the impaired receptor desensitization and internalization, but critically requires $\beta$ arr2-dependent signaling that depends on the SHSK motif in ICL3 of the receptor. Indeed, using ERK1/2 phosphorylation as a readout, we demonstrated that $\beta$ arr2-dependent signaling is enhanced and prolonged downstream of CXCR $4{ }^{1013}$. Removing the SHSK motif from CXCR4 ${ }^{1013}$ abolished $\beta$ arr2-dependent signaling (i.e. the late ERK1/2 phosphorylation, Figure 5) and the enhanced chemotactic responsiveness (Figure 2), although the resulting receptor $\left(\mathrm{CXCR} 4^{1013 / \Delta i 3}\right)$ retains G-protein-dependent signaling together with defective desensitization and internalization (Figures 3-5). A clue to explaining the requirement for the SHSK motif in the enhanced CXCR $4{ }^{1013}$-mediated chemotaxis may lie in its ability to help $\beta$ arr2 to act as a platform for the recruitment and the functional regulation of molecules involved in this signaling pathway. ${ }^{38}$ The requirement for $\beta$ arrs in CXCR4-mediated chemotaxis was first documented in cells from Barr2-deficient mice or after inhibition of $\beta$ arr2 expression by siRNA, ${ }^{7,8}$ and $\beta$ arr2 expression has also been found to strengthen the CXCL12-induced chemotaxis of CXCR4-expressing HEK cells. ${ }^{7}$ Here, we demonstrate that the last fifteen residues of the CXCR4 C-tail are not required for ßarr2 to regulate CXCL12-mediated chemotaxis. Indeed, CXCR $4{ }^{1013}$-mediated chemotaxis is substantially attenuated in Barr2-deficient cells and conversely, is increased after $\beta$ arr2 over-expression. Moreover, $\beta$ arr2 expression magnifies the enhanced migration of WHIM leukocytes (Figure 1). Barrs is involved in chemotaxis induced by other GPCRs including chemokine receptors, ${ }^{7,21}$ angiotensin-II type 1a receptor $\left(\mathrm{AT}_{1 \mathrm{~A}} \mathrm{R}\right)^{39}$ and protease-activated receptor-2 (PAR-2), ${ }^{40,41}$ and in some cases this process can occur independently of Gprotein coupling. Regarding CXCR4, $\beta$ arr2 is more likely to be involved in a G-protein-dependent chemotaxis, as this process requires the release of $G \beta \gamma$ subunits from activated $\mathrm{G}_{\mathrm{i}}$-proteins ${ }^{2}$ and is abrogated by PTX, which inactivates $\mathrm{G}_{i}$ proteins (Figure 2B). In fact, $\beta$ arrs can influence chemotaxis downstream of activated GPCRs by virtue of their ability to temporally coordinate and spatially control signaling of molecules involved in cytoskeleton reorganization, including members of the MAPK family, RhoA, PI3K and actin-binding proteins. ${ }^{38}$ To take PAR-2-mediated chemotaxis as an example, ßarrs bound to activated receptors sequester phosphorylated ERK1/2 along with the actin-filament severing protein cofilin to locally control actin assembly/disassembly at the leading edge of migrating cells. ${ }^{40,42}$ 
Both ERK and p38 MAPKs were found to be regulated by $\beta$ arr2 downstream of activated CXCR4. ${ }^{5,7}$ However, regulation of CXCR4-mediated migration by either of these two proteins differs between cell types (our unpublished observations and ref. ${ }^{7,43-45}$ ), thus suggesting that the components of the $\beta$ arr2dependent signaling pathway involved in cell migration may be cell-type specific. Recently, interactions between CXCR4 and the actin-binding protein filamin-A were suggested to play a role in regulating CXCL12-induced activation of the RhoA/ROCK pathway, myosin light chain phosphorylation, cofilin activity and finally chemotaxis. ${ }^{46}$ Interestingly, filamin-A was first identified as a ßarr-binding protein that provides a link between GPCR-induced $\beta$ arr-mediated signaling and cytoskeletal regulation. ${ }^{47,48}$ This raises the possibility that the filamin-A dependent signaling cascade may be set in motion downstream of activated CXCR $4^{\mathrm{m}}$.

Here, we report that CXCL12-induced ERK1/2 phosphorylation is enhanced in leukocytes from a WS patient with $\mathrm{CXCR} 4{ }^{1013}$ (Figure 5A), and we confirm in A0.01 cells the causative role of CXCR $4^{1013}$. Phosphorylated ERK1/2 plays roles in numerous cellular activities, including migration, cell proliferation and survival, and these depend on its duration, intensity and subcellular compartmentalization. ${ }^{49}$ Cytoplasmic and nuclear ERK1/2 has different functions and $\beta$ arr retains ERK1/2 in the cytoplasm, ${ }^{50,51}$ alters the time course of ERK1/2 phosphorylation and can modify ultimately the transcriptional response to receptor activation. ${ }^{52}$ These observations together with our results raise the possibility that ERK1/2-mediated responses are different in WHIM and control cells. In line with this, a recent study has revealed that CXCL12 acts as an anti-apoptotic factor for circulating neutrophils from WHIM patients, but not for neutrophils from a healthy individual, and the MEK1 inhibitor PD98059 suppressed this effect, thus indicating that survival of WHIM cells may be linked to MEK activation and the subsequent ERK1/2 phosphorylation. ${ }^{53}$

Previous studies have shown that $\beta$ arr2 interacts with the C-tail and ICL3 of CXCR $4,{ }^{5}$ and the results shown here allow for the possibility that the SHSK motif is required for Barr2 binding to ICL3. The deletion of either the C-tail or the SHSK motif allowed us to propose that each domain is dispensable for $\beta$ arr2 binding, and that the interactions of $\beta$ arr2 with either of these regions of CXCR4 can mediate distinct functions. Regulation of receptor desensitization and internalization is mediated by the receptor C-tail, and $\beta$ arr2 does not trigger endocytosis of the C-tail truncated receptors CXCR4 ${ }^{1013}$ and 
CXCR $4^{1013 / \Delta i 3}$. On the contrary, the C-tail is dispensable for $\beta$ arr2-mediated signaling, but this process requires the integrity of ICL3. Our observations that CXCR4 ${ }^{1013}$ exhibits enhanced $\beta$ arr-mediated signaling are consistent with a model where the interactions between $\beta$ arr2 and ICL3 of CXCR $4^{1013}$ are favored. It has been proposed that the C-tail covers ICL3 in the CXCR4 ${ }^{\mathrm{wt}}$ inactive state and then moves away to expose the loop when the receptor is activated. ${ }^{54}$ Accordingly, truncation of the CXCR4 C-tail might continuously expose ICL3 for $\beta$ arr binding, thus providing a molecular basis for the enhanced constitutive interactions that CXCR $4^{1013}$ exhibits with $\beta$ arr2 (Figure 1). Alternatively, but not exclusively, in accordance with a sequential multi-site binding model, ${ }^{55}$ ßarr2 may associate with both or either of the two regions of CXCR4 when $\beta$ arr2 encounters the receptor, so that truncation of the C-tail in CXCR4 ${ }^{1013}$ results in the privileged association with ICL3. This model is in line with our data showing that in the converse situation, in which the SHSK motif of CXCR $4^{\mathrm{wt}}$ is deleted (giving rise to $\mathrm{CXCR} 4^{\mathrm{w} / \Delta \mathrm{i}}$ ), the receptor is constitutively desensitized and internalized (Figures 3,4), possibly due to constitutive interactions of $\beta$ arr with the $C$-tail. Indeed, deleting the $\mathrm{C}$-tail in $\mathrm{CXCR} 4^{\mathrm{wt} / \Delta \mathrm{i} 3}\left(\mathrm{CXCR} 4^{1013 / \Delta \mathrm{i} 3}\right)$ abolishes constitutive desensitization and internalization. Thus, these results explain previous works showing that deleting the SHSK motif prevents CXCR4 from activating $\mathrm{G}_{\mathrm{i}}$-protein dependent signals, ${ }^{16,17}$ and uncover a key role for the SHSK motif in preventing CXCR4 from desensitization. They also suggest that ßarrs bound to ICL3 and G-proteins engage together on the receptor to concomitantly activate distinct $\beta$ arr- and G-protein-dependent signals.

Evidence is accumulating that GPCRs exist as dimers or as larger oligomers, ${ }^{56}$ and our results extend previous work showing that CXCR4 also forms constitutive oligomers. ${ }^{27,28,29}$ Dimerization plays roles in numerous receptor functions, including ligand binding, ${ }^{57}$ G-protein coupling ${ }^{58,59}$ and endocytosis ${ }^{60}$ and GPCRs can form heterodimers with new pharmacological properties compared to homodimers. ${ }^{56}$ Here, we show that $\mathrm{CXCR} 4{ }^{\mathrm{wt}} / \mathrm{CXCR} 4{ }^{1013}$ heterodimers form as efficiently as $\mathrm{CXCR} 4{ }^{\mathrm{wt}}$ homodimers and are at least two-fold more abundant than homodimers when both receptors coexist in the same cell at a $1 / 1$ ratio, thus suggesting that $\mathrm{CXCR} 4{ }^{\mathrm{wt}} / \mathrm{CXCR} 4{ }^{1013}$ heterodimers prevail in WHIM patients' cells. These data also explain how CXCR $4{ }^{1013}$ has a dominant-negative effect on CXCR4 ${ }^{\mathrm{wt}}$ endocytosis. ${ }^{11}$ Similarly to CXCR4 $4^{1013}$, other endocytosis-resistant GPCRs have been reported to prevent internalization by the 
formation of heterodimers, ${ }^{61,62}$ and in some cases this process could result from impaired $\beta$ arr recruitment by the heterodimers. These data are consistent with the notion that binding of $\beta$ arrs to GPCRs would require homodimer formation. As an example, activation of both subunits in an M3 muscarinic receptor dimer is required for $\beta$ arr recruitment, and association of this receptor with a mutated M3 receptor lacking Barr binding abrogates this recruitment. ${ }^{63}$ Similarly, one can speculate that $\beta$ arr2 must engage two CXCR4 molecules with an intact C-tail for an efficient receptor endocytosis, so that this process is impaired when $\mathrm{CXCR} 4^{\mathrm{wt}}$ associates with $\mathrm{CXCR} 4^{1013}$. On the other hand, expression of CXCR $4^{1013}$ in model cells reproduces the CXCR4 dysfunctions detected in WHIM leukocytes, thus suggesting that $\mathrm{CXCR} 4{ }^{\mathrm{wt}} / \mathrm{CXCR} 4{ }^{1013}$ heterodimers behave similarly to $\mathrm{CXCR} 4{ }^{1013}$ homodimers, and as such maintain the interactions with $\beta$ arr2 for signaling. In other words, it might be that a single CXCR $4^{1013}$ receptor in the CXCR $4{ }^{1013}$ homodimer or the CXCR $4{ }^{\mathrm{wt}} / \mathrm{CXCR} 4{ }^{1013}$ heterodimer preserves its ability to bind $\beta \mathrm{arr} 2$, thus providing a mechanism by which $\mathrm{CXCR} 4^{\mathrm{m}}$ alters the functioning of $\mathrm{CXCR} 4{ }^{\mathrm{wt}}$ in WHIM leukocytes. 


\section{ACKNOWLEDGMENTS}

This work was supported by the Institut National de la Santé et de la Recherche Médicale (INSERM), GIS-Network for rare diseases, la Ligue contre le Cancer, Ensemble contre le SIDA (SIDACTION) and the Agence Nationale de Recherches sur le SIDA (ANRS). KYCC was supported by scholarship from the Croucher foundation (Hong Kong), KB by a Young Investigator Fellowship from INSERM, AL by a fellowship from SIDACTION and JH by a grant from ANRS. We are indebted to the patient and his family for their cooperation and to Pr. J-F. Nicolas (Service de Pneumologie, CHU Lyon, France) for the provision of blood samples. We thank Dr M. Bouvier, Dr A. Brelot, Dr R. Jockers, Dr R. J. Lefkowitz, Dr S. Marullo and Dr M. Thelen for providing cDNAs and reagents as detailed in the text. We are grateful to Dr L. Burleigh (Unité de Pathogénie Virale Moléculaire, Institut Pasteur, Paris) for critical reading of the manuscript. 


\section{AUTHORSHIP}

Contribution: BL designed and performed research, collected, analyzed and interpreted data. F. Bachelerie designed research, analyzed data and performed the coordination and funding of the study. BL and F. Bachelerie wrote the manuscript. KYCC and KB performed experiments and analyzed data. AL, JH and TP contributed to experiments. KYCC, KB, TP and FAS edited the manuscript. FAS and NGS coordinated the patient cohort. F. Baleux performed chemokine synthesis.

Conflict of interest disclosure: The authors do not have conflict of interest and declare no competing financial interests. 


\section{REFERENCES}

1. Lapidot T, Dar A, Kollet O. How do stem cells find their way home? Blood. 2005;106:1901-1910.

2. Busillo JM, Benovic JL. Regulation of CXCR4 signaling. Biochim Biophys Acta. 2007;1768:952-963.

3. Haribabu B, Richardson RM, Fisher I, et al. Regulation of human chemokine receptors CXCR4. Role of phosphorylation in desensitization and internalization. J Biol Chem. 1997;272:28726-28731.

4. Orsini MJ, Parent JL, Mundell SJ, Benovic JL, Marchese A. Trafficking of the HIV coreceptor CXCR4. Role of arrestins and identification of residues in the c-terminal tail that mediate receptor internalization. J Biol Chem. 1999;274:31076-31086.

5. Cheng ZJ, Zhao J, Sun Y, et al. beta-arrestin differentially regulates the chemokine receptor CXCR4mediated signaling and receptor internalization, and this implicates multiple interaction sites between beta-arrestin and CXCR4. J Biol Chem. 2000;275:2479-2485.

6. Dewire SM, Ahn S, Lefkowitz RJ, Shenoy SK. beta-Arrestins and Cell Signaling. Annu Rev Physiol. 2007;69:483-510.

7. Sun Y, Cheng Z, Ma L, Pei G. Beta-arrestin2 is critically involved in CXCR4-mediated chemotaxis, and this is mediated by its enhancement of p38 MAPK activation. J Biol Chem. 2002;277:4921249219.

8. Fong AM, Premont RT, Richardson RM, Yu YR, Lefkowitz RJ, Patel DD. Defective lymphocyte chemotaxis in beta-arrestin2- and GRK6-deficient mice. Proc Natl Acad Sci U S A. 2002;99:74787483.

9. Gorlin RJ, Gelb B, Diaz GA, Lofsness KG, Pittelkow MR, Fenyk JR, Jr. WHIM syndrome, an autosomal dominant disorder: clinical, hematological, and molecular studies. Am J Med Genet. 2000;91:368-376. 
10. Gulino AV. WHIM syndrome: a genetic disorder of leukocyte trafficking. Curr Opin Allergy Clin Immunol. 2003;3:443-450.

11. Balabanian K, Lagane B, Pablos JL, et al. WHIM syndromes with different genetic anomalies are accounted for by impaired CXCR4 desensitization to CXCL12. Blood. 2005;105:2449-2457.

12. Gulino AV, Moratto D, Sozzani S, et al. Altered leukocyte response to CXCL12 in patients with warts hypogammaglobulinemia, infections, myelokathexis (WHIM) syndrome. Blood. 2004;104:444-452.

13. Hernandez PA, Gorlin RJ, Lukens JN, et al. Mutations in the chemokine receptor gene CXCR4 are associated with WHIM syndrome, a combined immunodeficiency disease. Nat Genet. 2003;34:70-74.

14. Kawai T, Choi U, Cardwell L, et al. WHIM syndrome myelokathexis reproduced in the NOD/SCID mouse xenotransplant model engrafted with healthy human stem cells transduced with C-terminus truncated CXCR4. Blood. 2007;109:78-84.

15. Kawai T, Choi U, Whiting-Theobald NL, et al. Enhanced function with decreased internalization of carboxy-terminus truncated CXCR4 responsible for WHIM syndrome. Exp Hematol. 2005;33:460468.

16. Ahr B, Denizot M, Robert-Hebmann V, Brelot A, Biard-Piechaczyk M. Identification of the cytoplasmic domains of CXCR4 involved in Jak2 and STAT3 phosphorylation. J Biol Chem. 2005;280:6692-6700.

17. Brelot A, Heveker N, Montes M, Alizon M. Identification of residues of CXCR4 critical for human immunodeficiency virus coreceptor and chemokine receptor activities. J Biol Chem. 2000;275:2373623744.

18. Amara A, Vidy A, Boulla G, et al. G protein-dependent CCR5 signaling is not required for efficient infection of primary $\mathrm{T}$ lymphocytes and macrophages by R5 human immunodeficiency virus type 1 isolates. J Virol. 2003;77:2550-2558.

19. Scott MG, Benmerah A, Muntaner O, Marullo S. Recruitment of activated G protein-coupled receptors to pre-existing clathrin-coated pits in living cells. J Biol Chem. 2002;277:3552-3559.

20. Couturier C, Jockers R. Activation of the leptin receptor by a ligand-induced conformational change of constitutive receptor dimers. J Biol Chem. 2003;278:26604-26611. 
21. Lagane B, Ballet S, Planchenault T, et al. Mutation of the DRY motif reveals different structural requirements for the $\mathrm{CC}$ chemokine receptor 5-mediated signaling and receptor endocytosis. Mol Pharmacol. 2005;67:1966-1976.

22. Gaibelet G, Planchenault T, Mazeres S, et al. CD4 and CCR5 constitutively interact at the plasma membrane of living cells: a confocal fluorescence resonance energy transfer-based approach. J Biol Chem. 2006;281:37921-37929.

23. Balabanian K, Lagane B, Infantino S, et al. The chemokine SDF-1/CXCL12 binds to and signals through the orphan receptor RDC1 in T lymphocytes. J Biol Chem. 2005;280:35760-35766.

24. Barak LS, Oakley RH, Laporte SA, Caron MG. Constitutive arrestin-mediated desensitization of a human vasopressin receptor mutant associated with nephrogenic diabetes insipidus. Proc Natl Acad Sci U S A. 2001;98:93-98.

25. Ahn S, Shenoy SK, Wei H, Lefkowitz RJ. Differential kinetic and spatial patterns of beta-arrestin and G protein-mediated ERK activation by the angiotensin II receptor. J Biol Chem. 2004;279:3551835525.

26. Gesty-Palmer D, Chen M, Reiter E, et al. Distinct beta-arrestin- and G protein-dependent pathways for parathyroid hormone receptor-stimulated ERK1/2 activation. J Biol Chem. 2006;281:10856-10864.

27. Babcock GJ, Farzan M, Sodroski J. Ligand-independent dimerization of CXCR4, a principal HIV-1 coreceptor. J Biol Chem. 2003;278:3378-3385.

28. Berchiche YA, Chow KY, Lagane B, et al. Direct assessment of CXCR4 mutant conformations reveals complex link between receptor structure and G(alpha)(i) activation. J Biol Chem. 2007;282:5111-5115.

29. Percherancier Y, Berchiche YA, Slight I, et al. Bioluminescence resonance energy transfer reveals ligand-induced conformational changes in CXCR4 homo- and heterodimers. J Biol Chem. 2005;280:9895-9903.

30. Ayoub MA, Levoye A, Delagrange P, Jockers R. Preferential formation of MT1/MT2 melatonin receptor heterodimers with distinct ligand interaction properties compared with MT2 homodimers. Mol Pharmacol. 2004;66:312-321. 
31. Terrillon S, Durroux T, Mouillac B, et al. Oxytocin and vasopressin V1a and V2 receptors form constitutive homo- and heterodimers during biosynthesis. Mol Endocrinol. 2003;17:677-691.

32. Urizar E, Montanelli L, Loy T, et al. Glycoprotein hormone receptors: link between receptor homodimerization and negative cooperativity. Embo J. 2005;24:1954-1964.

33. Marullo S, Bouvier M. Resonance energy transfer approaches in molecular pharmacology and beyond. Trends Pharmacol Sci. 2007;28:362-365.

34. Kim HK, De La Luz Sierra M, Williams CK, Gulino AV, Tosato G. G-CSF down-regulation of CXCR4 expression identified as a mechanism for mobilization of myeloid cells. Blood. 2006;108:812820.

35. Liles WC, Broxmeyer HE, Rodger E, et al. Mobilization of hematopoietic progenitor cells in healthy volunteers by AMD3100, a CXCR4 antagonist. Blood. 2003;102:2728-2730.

36. Martin C, Burdon PC, Bridger G, Gutierrez-Ramos JC, Williams TJ, Rankin SM. Chemokines acting via CXCR2 and CXCR4 control the release of neutrophils from the bone marrow and their return following senescence. Immunity. 2003;19:583-593.

37. Sawada S, Gowrishankar K, Kitamura R, et al. Disturbed CD4+ T cell homeostasis and in vitro HIV-1 susceptibility in transgenic mice expressing $\mathrm{T}$ cell line-tropic HIV-1 receptors. J Exp Med. $1998 ; 187: 1439-1449$.

38. Defea KA. Stop That Cell! beta-Arrestin-Dependent Chemotaxis: A Tale of Localized Actin Assembly and Receptor Desensitization. Annu Rev Physiol. 2007;69:535-560.

39. Hunton DL, Barnes WG, Kim J, et al. Beta-arrestin 2-dependent angiotensin II type 1A receptormediated pathway of chemotaxis. Mol Pharmacol. 2005;67:1229-1236.

40. Ge L, Ly Y, Hollenberg M, DeFea K. A beta-arrestin-dependent scaffold is associated with prolonged MAPK activation in pseudopodia during protease-activated receptor-2-induced chemotaxis. J Biol Chem. 2003;278:34418-34426.

41. Ge L, Shenoy SK, Lefkowitz RJ, et al. Constitutive protease-activated receptor-2-mediated migration of MDA MB-231 breast cancer cells requires both beta-arrestin-1 and -2. J Biol Chem. 2004;279:55419-55424. 
42. Zoudilova M, Kumar P, Ge L, Wang P, Bokoch GM, DeFea KA. Beta-arrestin-dependent regulation of the cofilin pathway downstream of protease-activated receptor-2. J Biol Chem. 2007;282:2063420646.

43. Alsayed Y, Ngo H, Runnels J, et al. Mechanisms of regulation of CXCR4/SDF-1 (CXCL12)dependent migration and homing in multiple myeloma. Blood. 2007;109:2708-2717.

44. Sotsios Y, Whittaker GC, Westwick J, Ward SG. The CXC chemokine stromal cell-derived factor activates a Gi-coupled phosphoinositide 3-kinase in T lymphocytes. J Immunol. 1999;163:5954-5963.

45. Wang JF, Park IW, Groopman JE. Stromal cell-derived factor-1alpha stimulates tyrosine phosphorylation of multiple focal adhesion proteins and induces migration of hematopoietic progenitor cells: roles of phosphoinositide-3 kinase and protein kinase C. Blood. 2000;95:2505-2513.

46. Jimenez-Baranda S, Gomez-Mouton C, Rojas A, et al. Filamin-A regulates actin-dependent clustering of HIV receptors. Nat Cell Biol. 2007;9:838-846.

47. Kim KM, Gainetdinov RR, Laporte SA, Caron MG, Barak LS. G protein-coupled receptor kinase regulates dopamine D3 receptor signaling by modulating the stability of a receptor-filamin-betaarrestin complex. A case of autoreceptor regulation. J Biol Chem. 2005;280:12774-12780.

48. Scott MG, Pierotti V, Storez H, et al. Cooperative regulation of extracellular signal-regulated kinase activation and cell shape change by filamin A and beta-arrestins. Mol Cell Biol. 2006;26:3432-3445.

49. Caunt CJ, Finch AR, Sedgley KR, McArdle CA. Seven-transmembrane receptor signalling and ERK compartmentalization. Trends Endocrinol Metab. 2006;17:276-283.

50. DeFea KA, Zalevsky J, Thoma MS, Dery O, Mullins RD, Bunnett NW. beta-arrestin-dependent endocytosis of proteinase-activated receptor 2 is required for intracellular targeting of activated ERK1/2. J Cell Biol. 2000;148:1267-1281.

51. Zhao M, Discipio RG, Wimmer AG, Schraufstatter IU. Regulation of CXCR4-mediated nuclear translocation of extracellular signal-related kinases 1 and 2. Mol Pharmacol. 2006;69:66-75.

52. Gesty-Palmer D, El Shewy H, Kohout TA, Luttrell LM. beta-Arrestin 2 expression determines the transcriptional response to lysophosphatidic acid stimulation in murine embryo fibroblasts. J Biol Chem. 2005;280:32157-32167. 
53. Sanmun D, Garwicz D, Smith CI, Palmblad J, Fadeel B. Stromal-derived factor-1 abolishes constitutive apoptosis of WHIM syndrome neutrophils harbouring a truncating CXCR4 mutation. Br J Haematol. 2006;134:640-644.

54. Ueda Y, Neel NF, Schutyser E, Raman D, Richmond A. Deletion of the COOH-terminal domain of CXC chemokine receptor 4 leads to the down-regulation of cell-to-cell contact, enhanced motility and proliferation in breast carcinoma cells. Cancer Res. 2006;66:5665-5675.

55. Gurevich VV, Gurevich EV. The molecular acrobatics of arrestin activation. Trends Pharmacol Sci. 2004;25:105-111.

56. Milligan G. G protein-coupled receptor dimerization: function and ligand pharmacology. Mol Pharmacol. 2004;66:1-7.

57. Springael JY, Le Minh PN, Urizar E, Costagliola S, Vassart G, Parmentier M. Allosteric modulation of binding properties between units of chemokine receptor homo- and hetero-oligomers. Mol Pharmacol. 2006;69:1652-1661.

58. Damian M, Martin A, Mesnier D, Pin JP, Baneres JL. Asymmetric conformational changes in a GPCR dimer controlled by G-proteins. Embo J. 2006;25:5693-5702.

59. Herrick-Davis K, Grinde E, Harrigan TJ, Mazurkiewicz JE. Inhibition of serotonin 5hydroxytryptamine2c receptor function through heterodimerization: receptor dimers bind two molecules of ligand and one G-protein. J Biol Chem. 2005;280:40144-40151.

60. Stanasila L, Perez JB, Vogel H, Cotecchia S. Oligomerization of the alpha 1a- and alpha 1b-adrenergic receptor subtypes. Potential implications in receptor internalization. J Biol Chem. 2003;278:4023940251.

61. Breit A, Lagace M, Bouvier M. Hetero-oligomerization between beta2- and beta3-adrenergic receptors generates a beta-adrenergic signaling unit with distinct functional properties. J Biol Chem. 2004;279:28756-28765.

62. Roumy M, Lorenzo C, Mazeres S, Bouchet S, Zajac JM, Mollereau C. Physical Association between Neuropeptide FF and \{micro\}-Opioid Receptors as a Possible Molecular Basis for Anti-opioid Activity. J Biol Chem. 2007;282:8332-8342. 
63. Novi F, Stanasila L, Giorgi F, Corsini GU, Cotecchia S, Maggio R. Paired activation of two components within muscarinic M3 receptor dimers is required for recruitment of beta-arrestin- 1 to the plasma membrane. J Biol Chem. 2005;280:19768-19776.

\section{FIGURE LEGENDS}

Figure 1. The WHIM-type receptor CXCR4 ${ }^{1013}$-mediated chemotaxis is dependent upon $\beta$ arr2. (A) The CXCR $4{ }^{1013}$ or its counterpart with the entire C-tail CXCR $4{ }^{\mathrm{wt}}$ was stably expressed at similar levels in HEK cells, as assessed by flow cytometry analysis using the PE-conjugated anti-CXCR4 mAb $12 \mathrm{G} 5$. These cells were then transiently transfected using the calcium phosphate-DNA coprecipitation method either with pN1-eGFP (N1) or p $\beta$-arrestin-2-eGFP ( $\beta$ arr2-GFP). Efficiency of transfection was in the same range for both cell types, with $40 \%-60 \%$ of transfected cells, as deduced from flow cytometry counting of cells with green fluorescence. $48 \mathrm{~h}$ post-transfection, cells were treated (+) or not (-) with 100 nM CXCL12 before immunoprecipitating of receptors. Receptors and $\beta$ arr2-GFP in the immunoprecipitates were detected by western blot analysis using the anti-CXCR4 SZ1567 and anti-ßarr2 polyclonal antibodies $\left(\mathrm{n}=3\right.$ ). (B) $48 \mathrm{~h}$ post-transfection, $3 \times 10^{5}$ transfected cells in $150 \mu \mathrm{l}$ DMEM supplemented with $20 \mathrm{mM}$ HEPES and $1 \%$ BSA were added to the upper chamber of a 8 - $\mu \mathrm{m}$ pore polycarbonate Transwell culture insert, and cell migration toward the indicated CXCL12 concentrations placed in the lower chamber proceeded for $4 \mathrm{~h}$. at $37^{\circ} \mathrm{C}$ in humidified air with $5 \% \mathrm{CO}_{2}$. The fraction of cells that migrated across the polycarbonate membrane was assessed by flow cytometry and was calculated as follows: [(number of cells migrating to the lower chamber in response to CXCL12) / (number of cells added to the upper chamber at the start of the assay)] x 100. The percentage of input cells with green fluorescence that migrated to the lower chamber was compared with that of input 
$\mathrm{CXCR}^{\mathrm{wt}}$ - and N1-expressing cells that migrated toward $0.1 \mathrm{nM} \mathrm{CXCL12}$ (arbitrarily set at 1 , and accounting for, on average, $2 \%$ of input cells). Spontaneous migrations were marginal in these experiments. The data are means \pm SEM ( $n=3$ ). (C) Migration of ßarr2-GFP- or N1-eGFP-expressing leukocytes from a healthy donor (CTRL) or a WHIM patient with the CXCR $4{ }^{1013}$ receptor was assessed as in (B) using a 5- $\mu \mathrm{m}$ pore polycarbonate Transwell culture insert and RPMI supplemented with HEPES and BSA as a migration medium. The percentage of input cells with green fluorescence that migrated to the lower chamber was compared with that of input N1-expressing control cells that migrated toward 0.3 nM CXCL12. Leukocytes were isolated as described ${ }^{11}$ and transfected using the Amaxa Nucleofector technology (D) $\mathrm{CXCR} 4{ }^{\mathrm{wt}}$ - or $\mathrm{CXCR} 4{ }^{1013}$-expressing HEK cells were transfected with small interfering RNA (siRNA) targeting ßarr2 or control siRNA (NT). $48 \mathrm{~h}$ after transfection, cell lysates were prepared and expression of $\beta$ arr2, $\beta$ arr1 or LDH was assessed by western blot analysis as described in the 'material and methods' section (E) Chemotaxis of siRNA-treated cells was carried out as in (B). The data represent means $\pm \operatorname{SEM}(\mathrm{n}=2)$.

Figure 2. CXCR4 ${ }^{\mathbf{1 0 1 3}}$-mediated chemotaxis depends on the SHSK motif of the receptor. (A) A0.01 T cells were transduced to express identical amounts of $\mathrm{CXCR} 44^{\mathrm{wt}}, \mathrm{CXCR} 4^{1013}$ or the receptors lacking the SHSK motif, CXCR $4^{\mathrm{wt} / \Delta \mathrm{i} 3}$ or CXCR $4^{1013 / \Delta \mathrm{i} 3}$. The panel shows typical cell surface expression levels of $\mathrm{CXCR}^{\mathrm{wt}}$ (regular line) and CXCR $4^{1013}$ (dotted line), as assessed by flow cytometry analysis using PEconjugated 12G5, compared to parental cells (filled peak). The inset depicts the expression levels of CXCR $4^{1013}$ (grey bar), CXCR4 ${ }^{\mathrm{wt} / \Delta \mathrm{i} 3}$ (black bar) and CXCR4 ${ }^{1013 / \Delta \mathrm{i3}}$ (hatched bar) compared with that of $\mathrm{CXCR} 4{ }^{\mathrm{wt}}$ arbitrarily set at $100 \%$ (open bar). Data are means \pm SEM ( $\mathrm{n}=3$ ). (B) Transduced cells were subjected to CXCL12-induced chemotaxis as in Fig. 1C. The transmigrated cells recovered in the lower chamber were counted by flow cytometry. The data (means \pm SEM, $n=3$ ) represent chemotactic indexes that were calculated as follows: (number of cells that migrated toward CXCL12) / (number of cells that migrated spontaneously). Spontaneous migrations were in the same range for all cell populations, reaching $4.4 \pm 1.8 \%, 3.8 \pm 2.2 \%, 4.2 \pm 2.2 \%$ and $3.6 \pm 0.6 \%$ of input $\mathrm{CXCR}^{\mathrm{wt}}{ }_{-}, \mathrm{CXCR} 4^{1013}-$, CXCR $4^{\mathrm{wt} / \Delta \mathrm{i} 3}$ - and CXCR $4^{1013 / \Delta \mathrm{i} 3}$-expressing cells, respectively. As also shown in the panel, pretreating CXCR4 $4^{\mathrm{wt}}$ - or CXCR $4{ }^{1013}$-expressing cells with Bordetella Pertussis toxin (PTX) at $0.5 \mu \mathrm{M}$ for 90 min 
abrogated CXCL12-dependent migration. ${ }^{*}, P<0.05$, compared to cells with the other receptors in unpaired one-tailed student's t test.

Figure 3. The C-tail and the SHSK motif of CXCR4 regulate activation of G-proteins and receptor down-modulation. (A and B) $\mathrm{CXCR} 4{ }^{\mathrm{wt}}, \mathrm{CXCR} 4^{1013}, \mathrm{CXCR} 4^{\mathrm{wt} / \Delta \mathrm{i} 3}$ and $\mathrm{CXCR} 4^{1013 / \Delta \mathrm{i} 3}$ were transiently expressed in HEK cells. Flow cytometry analysis using PE-conjugated 12G5 confirmed similar expression levels of receptors at the cell surface. Staining of parental cells was used as a negative control (filled peaks). (C) CXCL12-induced $\left[{ }^{35} \mathrm{~S}\right] \mathrm{GTP} \gamma \mathrm{S}$ binding to membranes from these cells transiently expressing CXCR4 ${ }^{\mathrm{wt}}$ (filled squares), $\mathrm{CXCR} 4^{1013}$ (open squares), $\mathrm{CXCR} 4^{\mathrm{wt} / \Delta \mathrm{i} 3}$ (filled circles) or CXCR $4^{1013 / \Delta \mathrm{i} 3}$ (open circles) is shown. Membranes were incubated in assay buffer containing $0.1 \mathrm{nM}$ $\left[{ }^{35} \mathrm{~S}\right] \mathrm{GTP} \gamma \mathrm{S}$ and the indicated concentrations of CXCL12. The data, which are representative of 4 independent experiments performed in triplicate, are expressed as percentage of the basal binding to CXCR $4{ }^{\text {wt }}$-expressing membranes. (D) Receptor expression levels following stimulation with $200 \mathrm{nM}$ CXCL12 for $45 \mathrm{~min}$ at $37^{\circ} \mathrm{C}$ are shown. Results (means $\pm \mathrm{SD}, \mathrm{n}=3$ ) indicate the amount of receptor that remains at the surface of HEK cells expressing $\mathrm{CXCR}^{\mathrm{wt}}$ (open bar), CXCR4 ${ }^{1013}$ (dark grey bar), CXCR $4^{\mathrm{wt} / \Delta \mathrm{i} 3}$ (black bar) or CXCR $4^{1013 / \Delta \mathrm{i3}}$ (hatched bar) after incubation with CXCL12, compared with untreated cells (n.s., light grey bar).

Figure 4. The SHSK motif prevents CXCR4 from constitutive down-modulation. (A and B) Effects of $\beta$ arr2 on cell surface expression of $\mathrm{CXCR} 4^{\mathrm{wt}}$ (panel A), $\mathrm{CXCR} 4^{1013}$ (panel A), $\mathrm{CXCR} 4^{\mathrm{w} t / \mathrm{i} 3}$ (panel B) and CXCR $4^{1013 / \Delta i 3}$ (panel B). HEK cells stably expressing either of the CXCR4 variants were transiently transfected with pN1-eGFP (N1) or ßarr2-GFP. Expression of receptors without (open bars) or with treatment with $200 \mathrm{nM} \mathrm{CXCL12} \mathrm{for} 45 \mathrm{~min}$ at $37^{\circ} \mathrm{C}$ (filled bars) was then assessed by flow cytometry. Results (means $\pm \mathrm{SD}, \mathrm{n}=3$ ) are receptor expression at the surface of GFP-positive gated cells, expressed as percentage of the values in GFP-positive, pN1-eGFP-transfected cells in the absence of CXCL12 $(100 \%)$. (C-F) The dot plots from flow cytometry assays represent cell surface expression of CXCR4 ${ }^{\mathrm{wt}}$ (C), $\mathrm{CXCR}^{1013}$ (D), $\mathrm{CXCR}^{\mathrm{wt} / \Delta \mathrm{i} 3}$ (E) or CXCR4 $4^{1013 / \Delta \mathrm{i} 3}$ (F) as a function of $\beta$ arr2-GFP expression, i.e. GFP fluorescence intensity, in transiently co-transfected HEK cells. Experiments $(n=3)$ were carried out 
48h post-transfection. (G) Fluorescence microscopy imaging of HEK cells stably expressing the GFPtagged CXCR4 variant receptors.

Figure 5. Enhanced and sustained CXCR4 ${ }^{1013}$-mediated ERK1/2 activation depends on the SHSK motif. (A) A representative experiment out of 2 showing CXCL12-induced ERK1/2 activation in leukocytes from a healthy subject (CTRL) or a WHIM patient harboring CXCR4 ${ }^{1013}$, with $(+)$ or without (-) $30 \mathrm{nM} \mathrm{CXCL12}$ for 2 min at $37^{\circ} \mathrm{C}$. Cell lysates were immunoblotted for ERK2 and phosphorylated ERK1/2 and data were quantified as P-ERK/ERK2 ratios. (B and C) Time course of CXCL12-induced ERK1/2 phosphorylation in transduced A0.01 $\mathrm{T}$ cells expressing similar amounts of CXCR4 ${ }^{\mathrm{wt}}$, $\mathrm{CXCR} 4^{1013}, \mathrm{CXCR} 4^{\mathrm{wt} / \Delta \mathrm{i} 3}$ or CXCR4 ${ }^{1013 / \Delta \mathrm{i} 3}$ (see Figure $2 \mathrm{~A}$ ). Cells were stimulated with $30 \mathrm{nM}$ CXCL12 for 2, 5 or $15 \mathrm{~min}$, or not (0), and the ERK2 and phosphorylated ERK1/2 content in the cell lysates was analyzed as in (A). Immunoblots for ERK2 and phosphorylated ERK1/2 from a representative experiment are depicted in panel $(B)$. The values in panel $(C)($ mean \pm SEM, $n=3)$ represent ERK1/2 activation quantified as P-ERK/ERK2 ratios in cells expressing $\mathrm{CXCR} 44^{\mathrm{wt}}, \mathrm{CXCR} 4^{1013}, \mathrm{CXCR} 4^{\mathrm{wt} / \Delta \mathrm{i} 3}$ or CXCR $4^{1013 / \Delta \mathrm{i} 3}$, expressed as a percent of the ERK1/2 activation in CXCR4 ${ }^{\mathrm{wt}}$-expressing cells at 2 min stimulation $(100 \%)$.

Figure 6. Effects of $\beta$ arr2 siRNA on CXCR4 $^{1013}$-mediated ERK1/2 activation. A0.01 $\mathrm{T}$ cells expressing $\mathrm{CXCR} 4{ }^{\mathrm{wt}}$ or $\mathrm{CXCR} 4{ }^{1013}$ were nucleoporated with siRNA targeting $\beta$ arr2 or control siRNA (NT). $48 \mathrm{~h}$ after transfection, cells were stimulated or not with 10nM CXCL12 for 15 (B and C) or 2 min (C). Cell lysates were prepared and $20 \mu \mathrm{g}$ of proteins was used to visualize expression of $\beta$ arr2 (A) and ERK1/2 phosphorylation (B and C). Representative results $(n=3)$ are shown in panels (A) and (B). In panel (C), ERK1/2 phosphorylation is expressed as a ratio of activated ERK1/2 over total ERK2, and ratios with $\beta$ arr2 siRNA are compared with those from cells with control siRNA (arbitrarily set at 1). Results are means $\pm \mathrm{SEM}$.

Figure 7. CXCR4 ${ }^{\mathrm{wt}}$ and $\mathrm{CXCR} 4^{1013}$ form constitutive heterodimers. (A) Coimmunoprecipitation of CXCR $4^{1013}$ and CXCR4 ${ }^{\mathrm{wt}}$. HEK cells stably expressing CXCR4 ${ }^{\mathrm{wt}}$ (wt) were transfected or not with a 
CXCR $4^{1013}$ receptor variant fused to GFP at its N-tail $\left(1013^{\mathrm{GFP}}\right) .48 \mathrm{~h}$. post-transfection, cells were incubated without (left and right panels) or with (left panel) $100 \mathrm{nM} \mathrm{CXCL12}$ for $15 \mathrm{~min}$ in PBS at $37^{\circ} \mathrm{C}$, treated or not with the disuccinimidyl suberate (DSS) covalent cross-linker, and receptors were immunoprecipitated using the anti-CXCR4 mAb 12G5. Immunoprecipitated receptors were analyzed by western blotting as described in Fig. 1. Left and right panels are representative experiments performed with two different GFP-CXCR4 ${ }^{1013}$ to $\mathrm{CXCR} 4{ }^{\mathrm{wt}}$ ratios (R), which were calculated using a LAS-1000 CCD camera with the Image Gauge 3.4 software. Experiments with parental cells (P) are also shown. The arrowheads indicate monomeric CXCR $4^{\mathrm{wt}}$ and GFP-CXCR $4^{1013}$ at 41 and $59 \mathrm{kDa}$ respectively, and the arrows indicate GFP-CXCR $4{ }^{1013} / \mathrm{CXCR} 4^{\mathrm{wt}}$ heterodimers at $100 \mathrm{kDa}$. (B and C) Detection of receptor dimerization using BRET titration experiments. HEK cells were transfected using the transfection reagent FuGene 6 with constant amounts of cDNA coding for CXCR4 ${ }^{\text {wt }}$-RLuc (50 ng / well in 6-well dishes) and increasing amounts (from $25 \mathrm{ng}$ up to $1000 \mathrm{ng}$ ) of cDNA encoding for CXCR4 ${ }^{\mathrm{wt}}$-YFP (B, circles), YFP alone (B, diamonds), CXCR4 $4^{1013}$-YFP (C, squares) or GBR2-YFP (C, triangles). Experiments were carried out $48 \mathrm{~h}$. post-transfection. Total fluorescence (determined using an excitation filter at $485 \mathrm{~nm}$ ) and luminescence were used as relative measures of total expression of the RLuc- and YFP-tagged proteins. The $\mathrm{CXCR} 4^{\mathrm{wt}}$-RLuc receptor amounts were roughly similar in the experimental conditions tested. BRET values, expressed as percent of the maximal BRET reached (BRETmax), are plotted as a function of the ratio of YFP/RLuc fusion proteins. Plotted results are from 3 independent experiments. 
Figure 1

Lagane et al.,

A

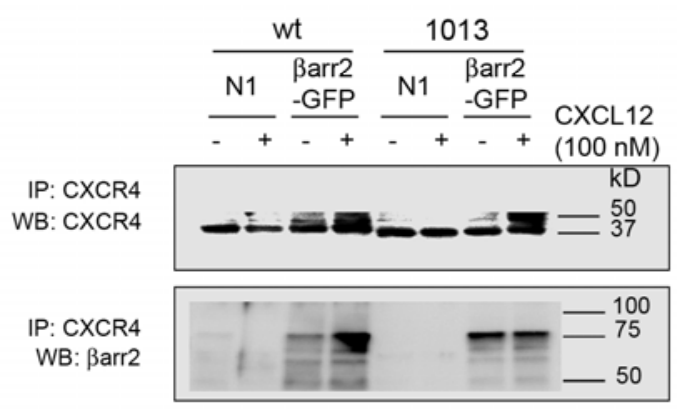

B

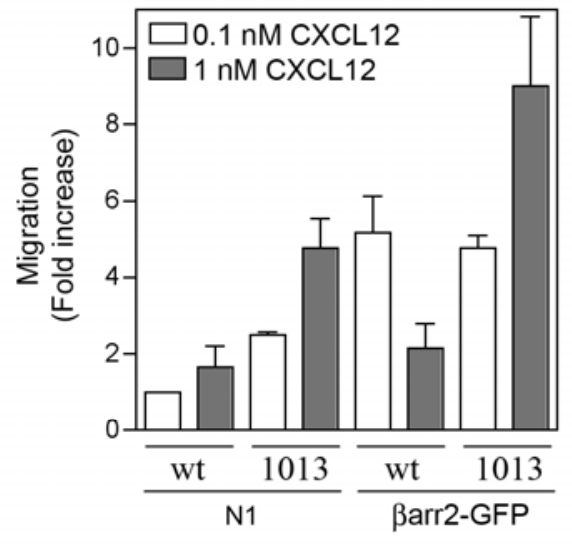

D

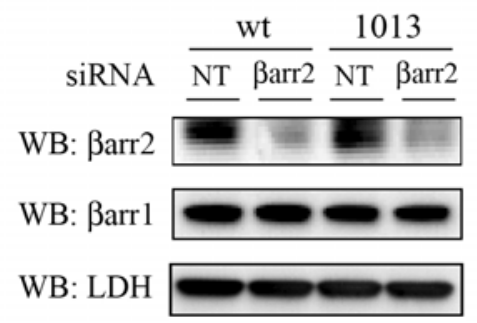

C

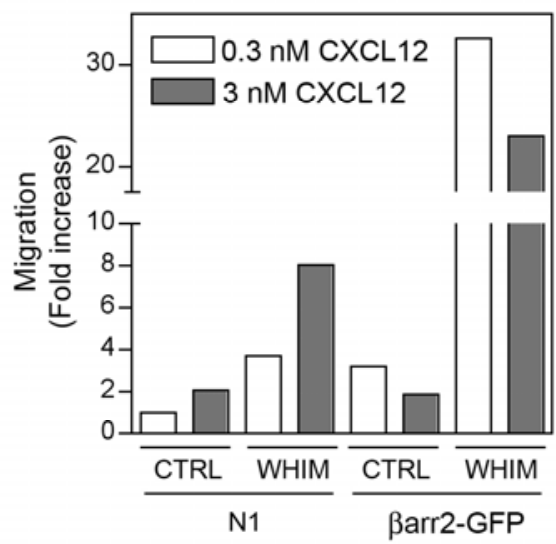

E

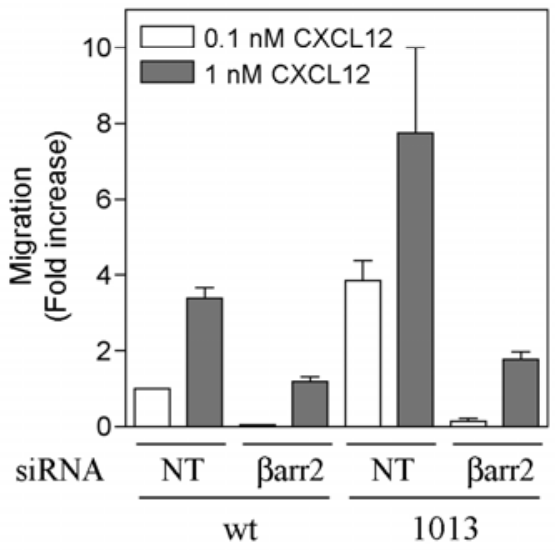


Figure 2

Lagane et al.,

$\mathbf{A}$

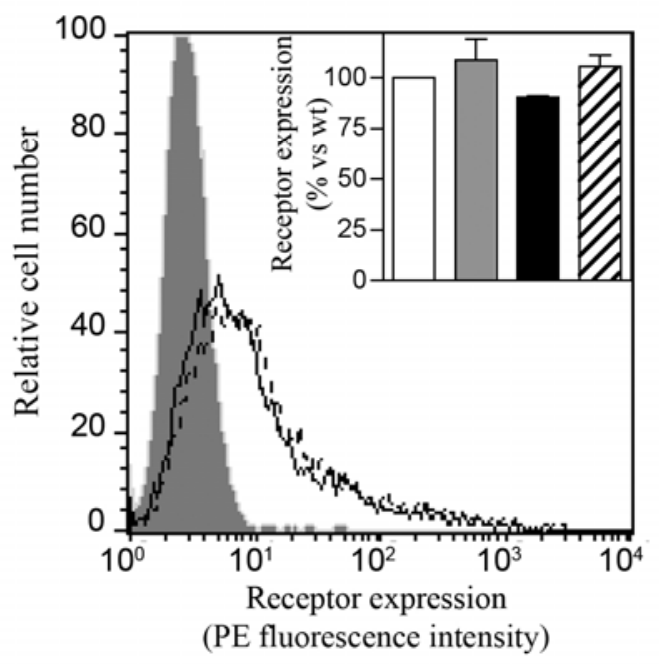

B

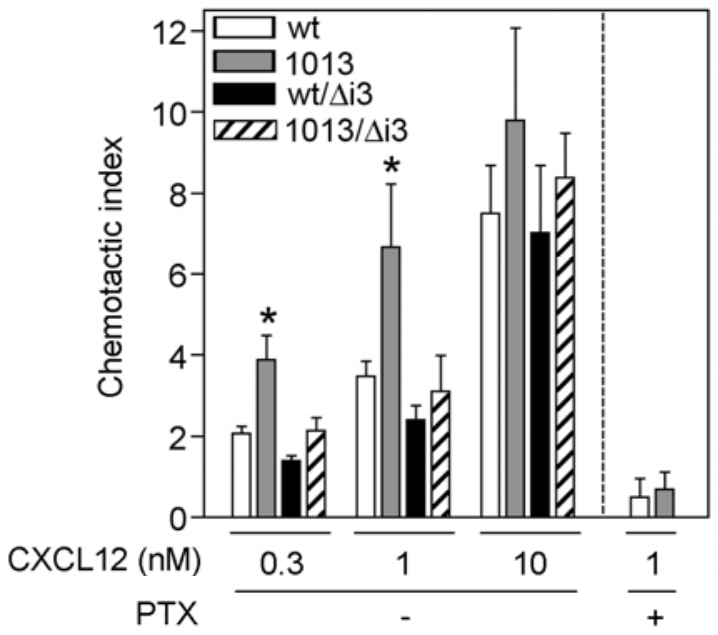




\section{Figure 3}

Lagane et al.,

A

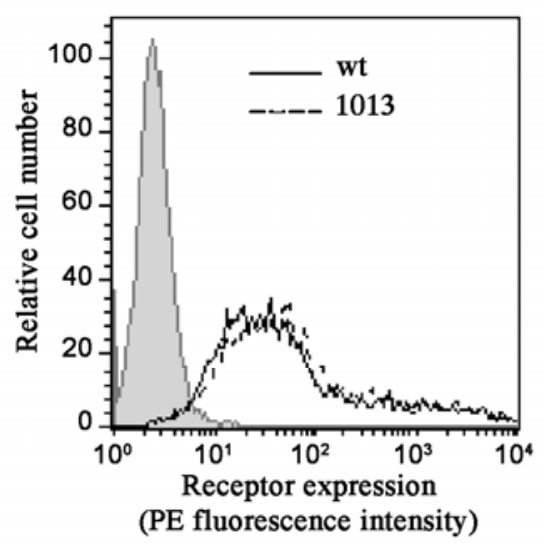

C

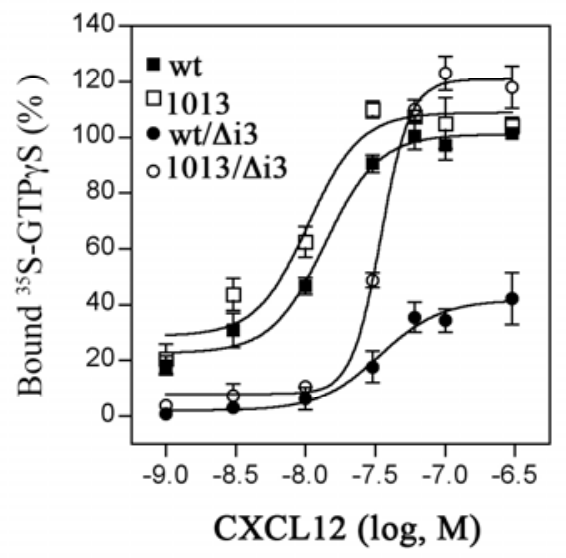

B

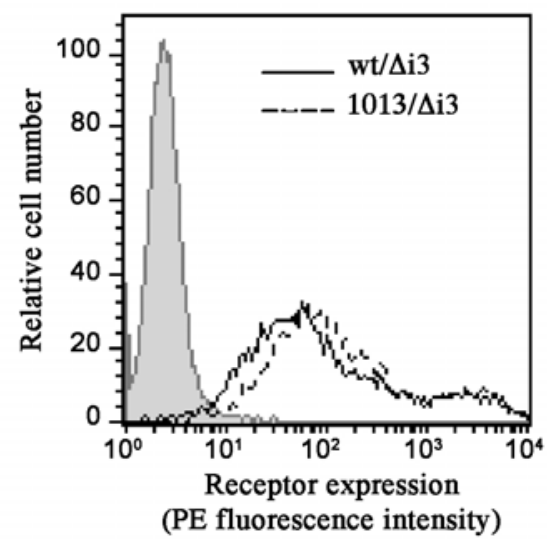

D

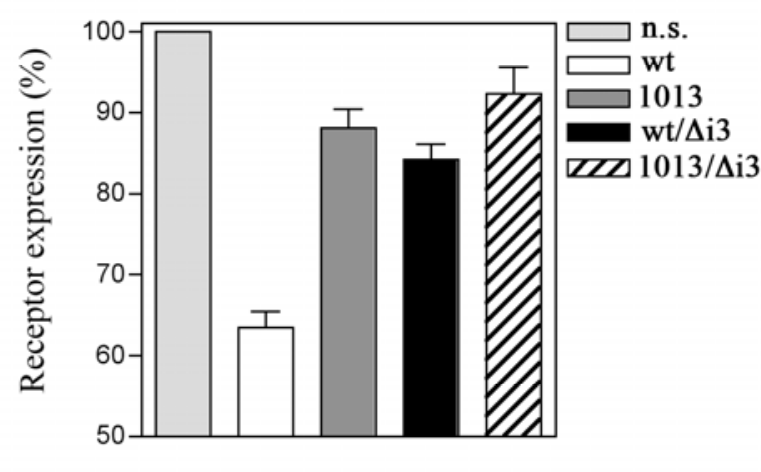


Figure 4

Lagane et al.,

A

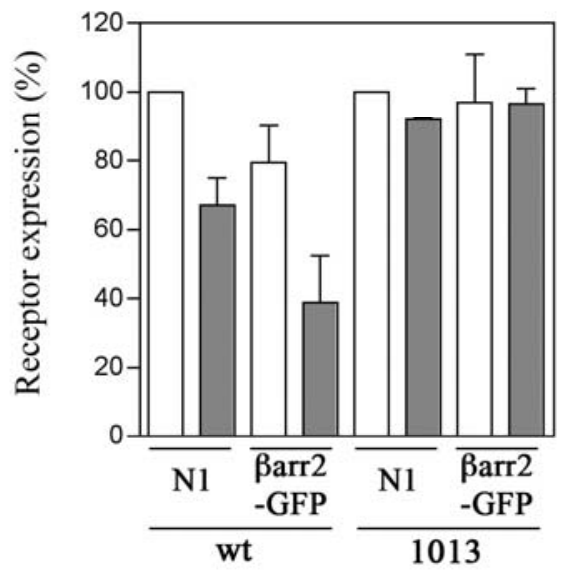

C
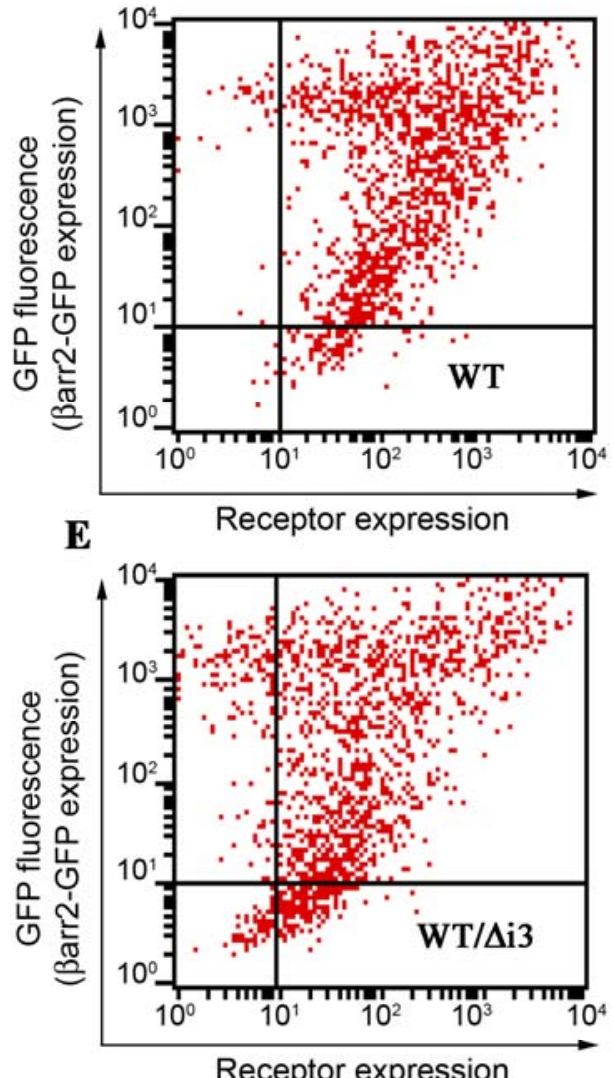

B

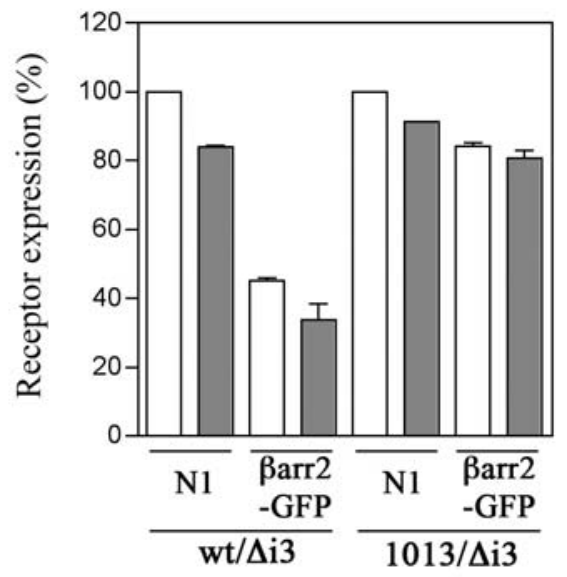

D
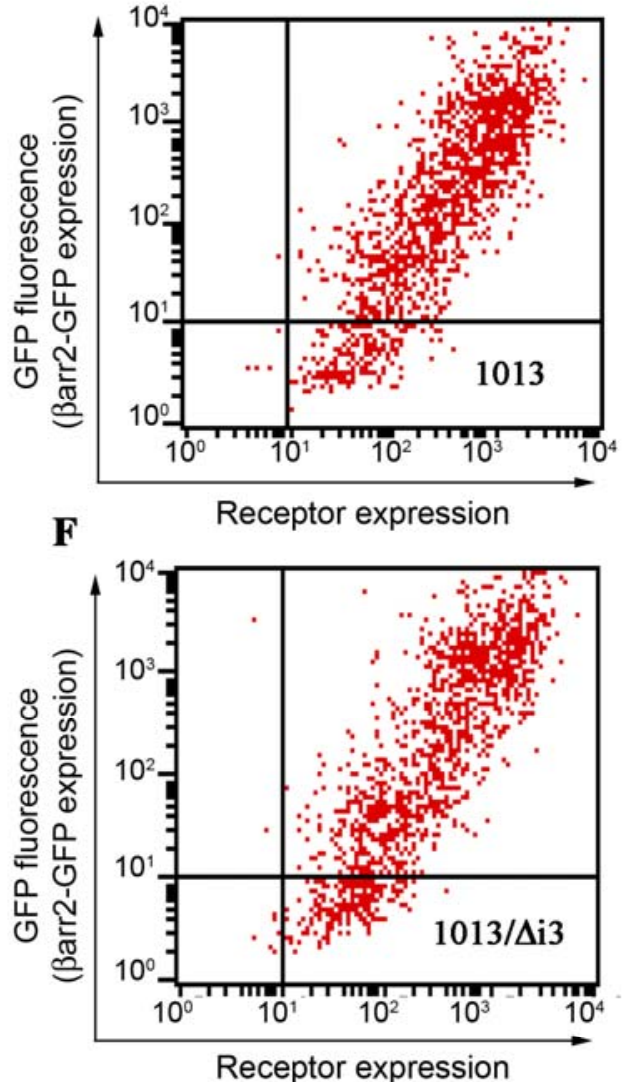
Figure 4

Lagane et al.,

G

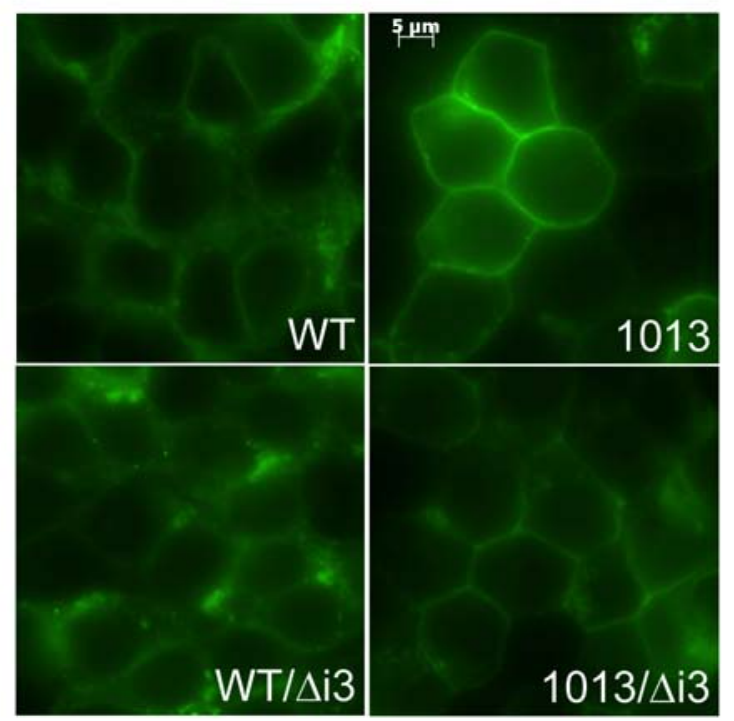


Figure 5

Lagane et al.,

A

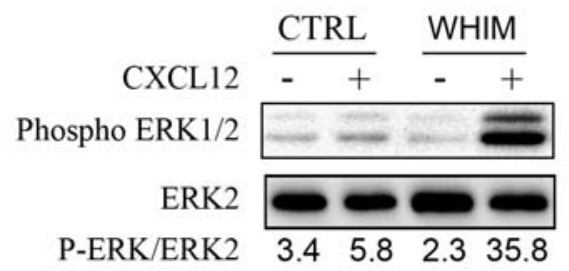

B

Agonist:

CXCL12 (30 nM)

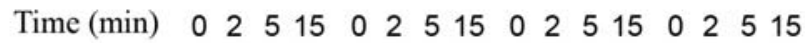

Phospho ERK1/2 ニーー ニニニ ミニー ニニ

ERK 2 -1-7-m-10-1-

wt $\frac{1013}{\mathrm{wt} / \Delta \mathrm{i} 3} \overline{1013 / \Delta \mathrm{i} 3}$

C

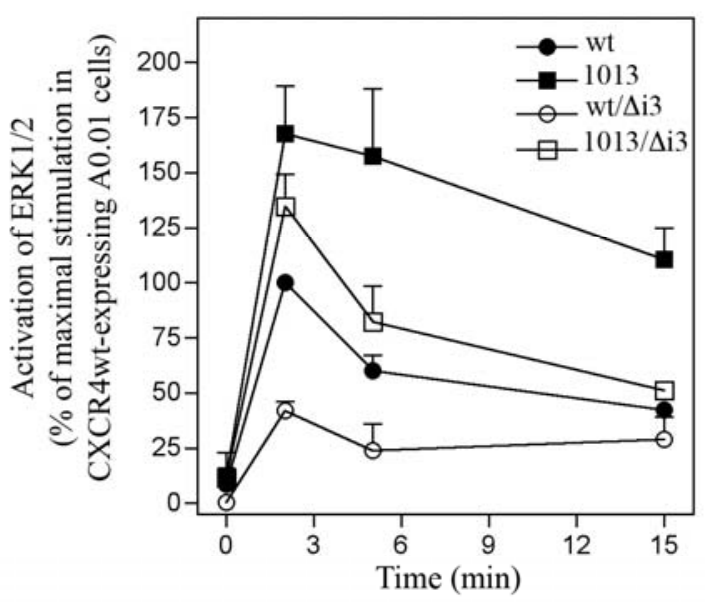


Figure 6

Lagane et al.,

A

\begin{tabular}{|c|c|c|c|c|}
\hline \multirow[b]{2}{*}{ siRNA } & \multicolumn{2}{|c|}{$\mathrm{CXCR}^{\mathrm{wt}}$} & \multicolumn{2}{|c|}{$\mathrm{CXCR} 4^{1013}$} \\
\hline & NT & ßarr2 & NT & ßarr2 \\
\hline B: $\beta \operatorname{arr} 2$ & & -1 & 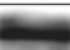 & -1 \\
\hline
\end{tabular}

B

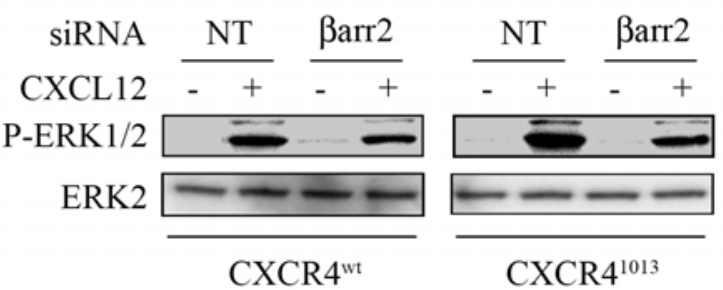

C

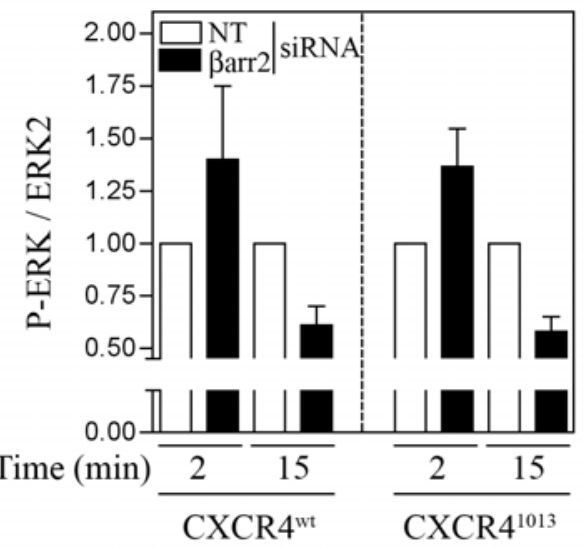


Figure 7

Lagane et al.,

A
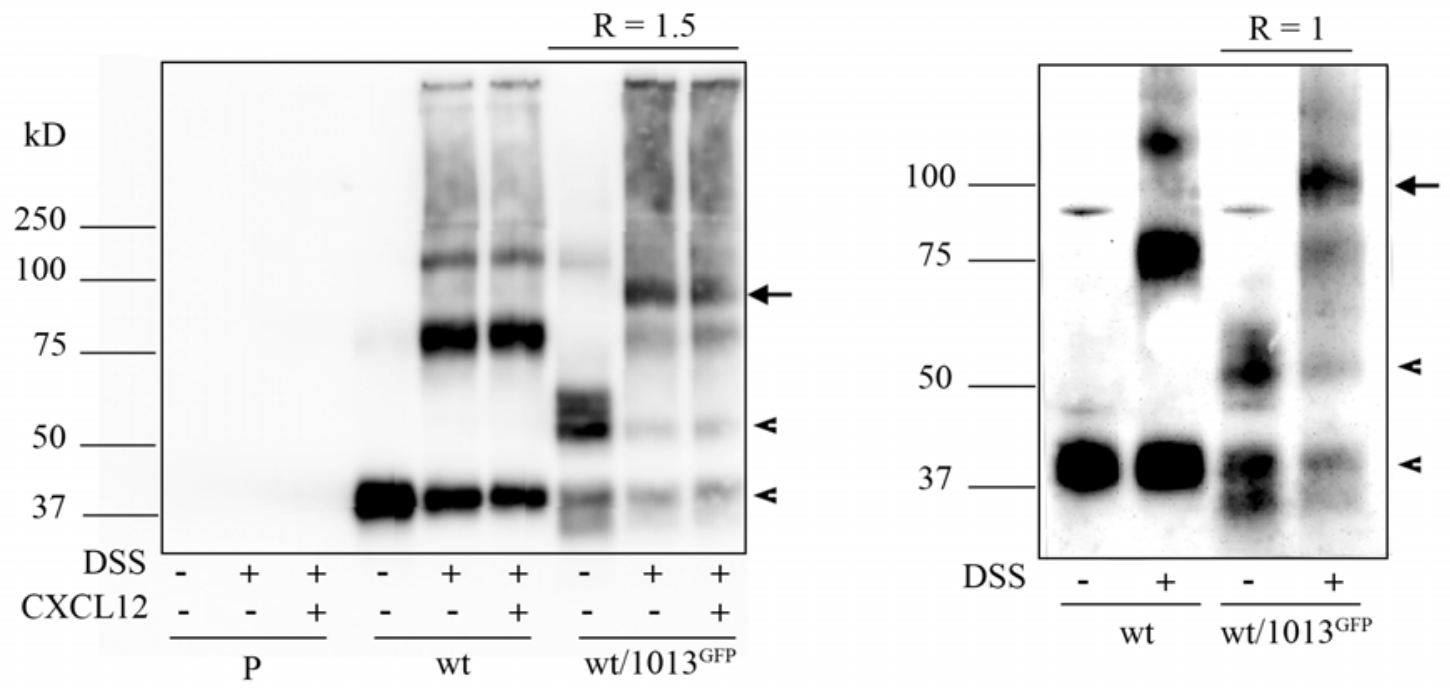

B

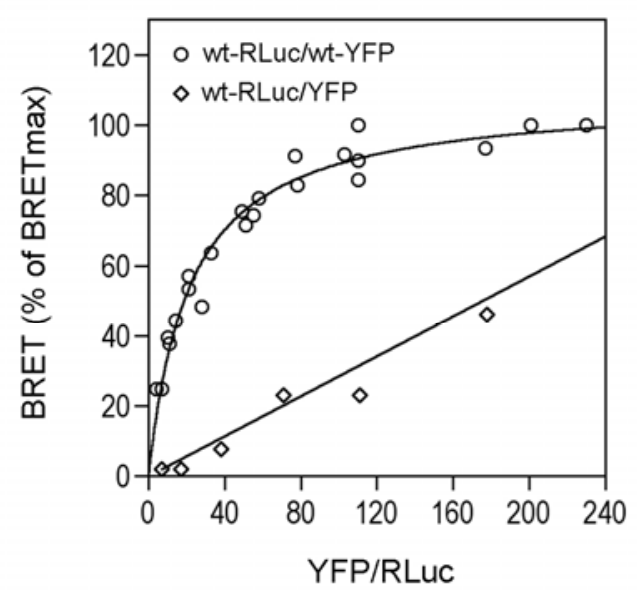

C

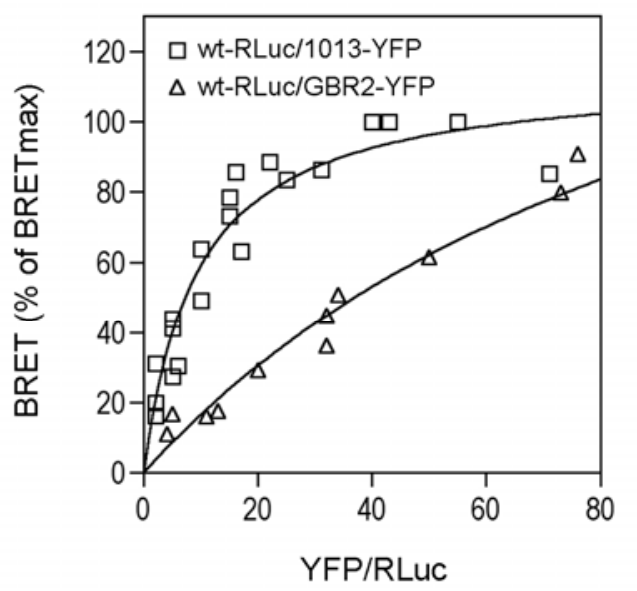

